$5-1984$

\title{
Archeological and Historical Investigations at 41TT310, Lake Bob Sandlin State Park, Titus County, Texas
}

Daniel J. Prikryl

Prewitt and Associates, Inc.

Kathleen Gilmore

Prewitt and Associates, Inc.

Ross C. Fields

Prewitt and Associates, Inc.

Nancy Reese

Prewitt and Associates, Inc.

Follow this and additional works at: https://scholarworks.sfasu.edu/ita

Part of the American Material Culture Commons, Archaeological Anthropology Commons, Environmental Studies Commons, Other American Studies Commons, Other Arts and Humanities Commons, Other History of Art, Architecture, and Archaeology Commons, and the United States History Commons

Tell us how this article helped you.

This Article is brought to you for free and open access by the Center for Regional Heritage Research at SFA ScholarWorks. It has been accepted for inclusion in Index of Texas Archaeology: Open Access Gray Literature from the Lone Star State by an authorized editor of SFA ScholarWorks. For more information, please contact cdsscholarworks@sfasu.edu. 


\section{Archeological and Historical Investigations at 41TT310, Lake Bob Sandlin State Park, Titus County, Texas}

\section{Creative Commons License}

\section{(c) (1) $\Theta(9$}

This work is licensed under a Creative Commons Attribution-NonCommercial-No Derivative Works 4.0 International License. 


\section{ARCHEOLOGICAL AND HISTORICAL INVESTIGATIONS \\ AT 41TT310, LAKE BOB SANDLIN STATE PARK, TITUS COUNTY, TEXAS}

by

Daniel J. Prikryl

Kathleen Gilmore

Ross C. Fields

and

Nancy Reese

Co-Principal Investigators: Ross C. Fields and Kathleen Gilmore

REPORTS OF INVESTIGATIONS, NUMBER 27

Submitted to

Texas Parks and Wildlife Department

Austin, Texas

by

Prewitt and Associates, Inc.

Consulting Archeologists

Austin, Texas

May 1984

Texas Antiquities Permit Number 387 





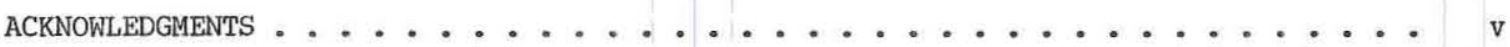

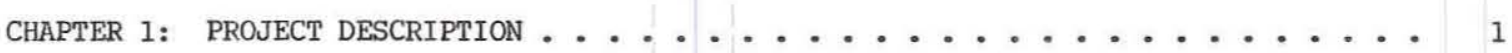

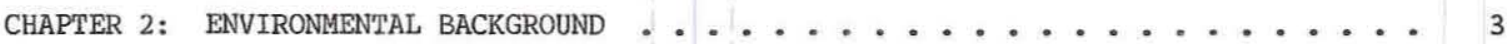

CHAPTER 3: ARCHEOLOGICAL AND HISTORICAL BACKGROUND . . . . . . . . . . . . . 5

Native Culture History . . . . . . . . . . . . . . . 5



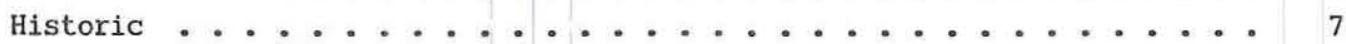

Review of Anglo-American History . . . . . . . . . . . . . 8

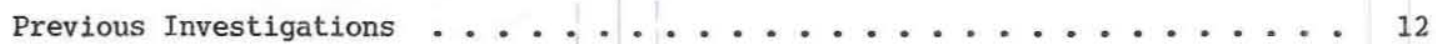

CHAPTER 4 : RESEARCH STRATEGY AND TEChNIQUES $\ldots \ldots \ldots \ldots$

Summary of Survey Information . . . . . . . . . . . . . . 15

Objectives of the Project ......................... 15

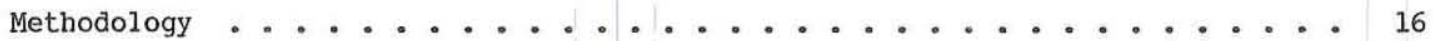

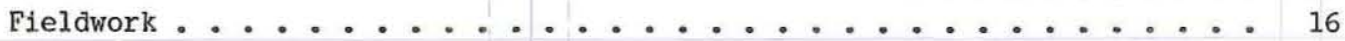

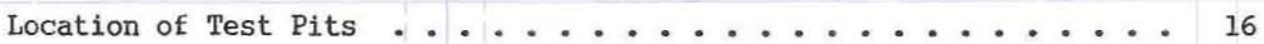

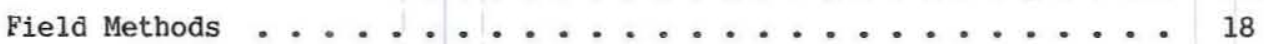

Laboratory Procedures ......................... 18

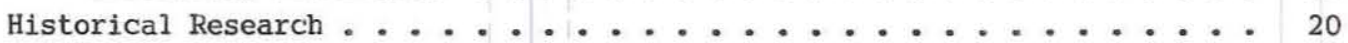

CHAPTER 5: RESULTS OF INVESTIGATIONS . . . . . . . . . . . . . 21

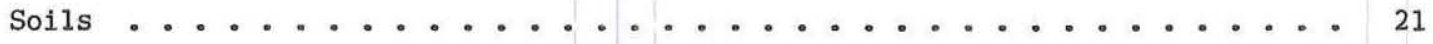

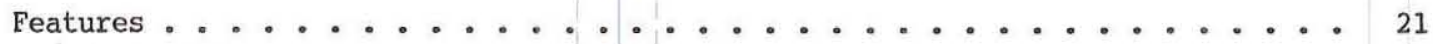

Feature $1 \ldots \ldots \ldots 21$

Feature $2 \ldots \ldots \ldots 22$

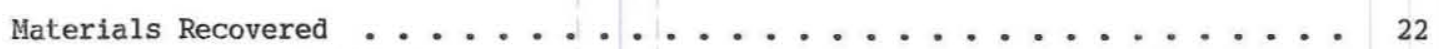

Prehistoric Artifacts ........................ 22

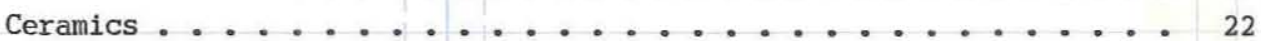

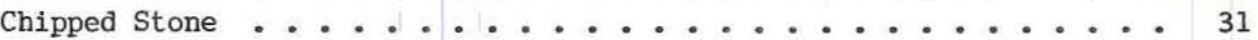

Miscellaneous Stone Artifacts ............... 42

Historic Artifacts ................. 43

Ceramics ......................... 43





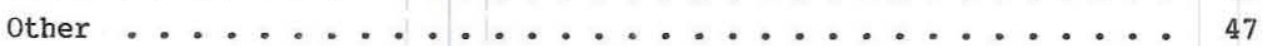



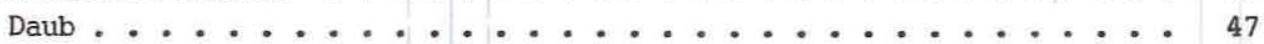



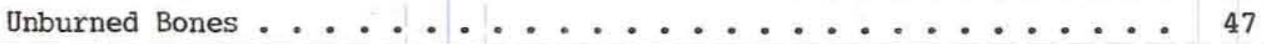




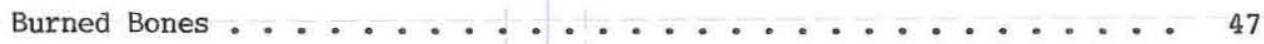

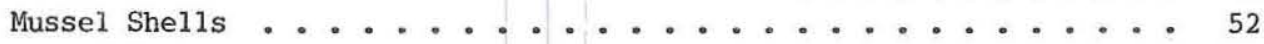

Burned Rocks ........................... 52

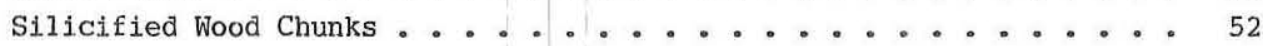

Assessment of Historic Component ................... 52

Assessment of Prehistoric Components . . . . . . . . . . . . . 54

Site Formation Processes ............... . . . 54

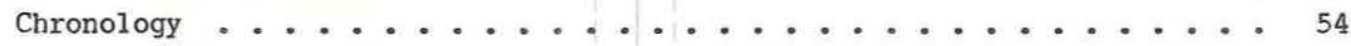

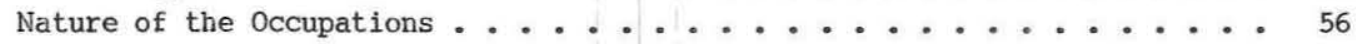

CHAPTER 6 : SUMMARY AND RECOMMENDATIONS ................. 61

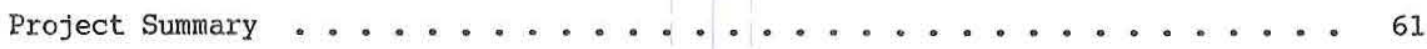

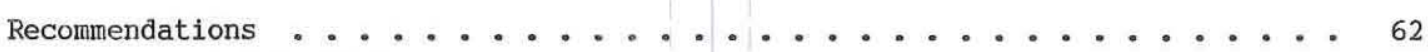

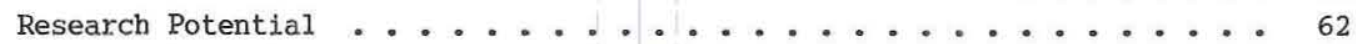

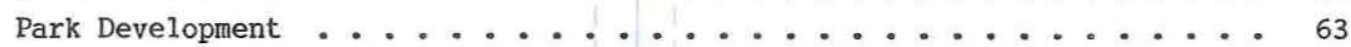

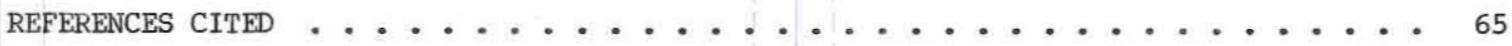

LIST OF FIGURES

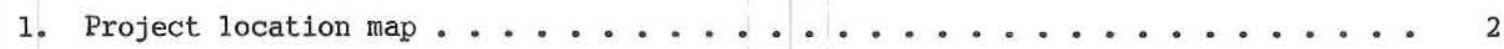

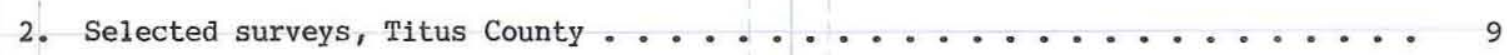



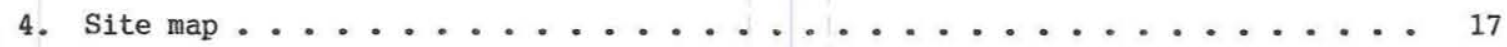

5. Photographs of excavations . . . . . . . . . . . . . . . 19

6. Test Pits A and B, east wall profile ................ 23





9. Vertical distribution of combined lithic debitage and ceramics . . . . . 55

10. Vertical distribution of artifacts ............... 57

LIST OF TABLES

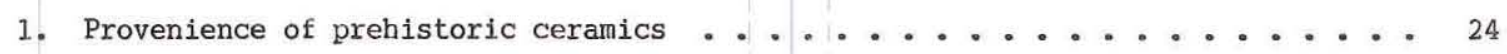



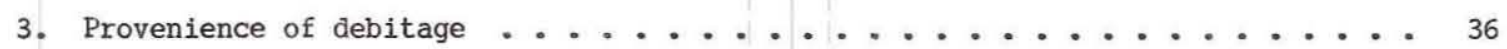

4. Provenience of historic artifacts ... . . . . . . . . . . . 44

5. Provenience of nonartifactual remains . . . . . . . . . . . 48 


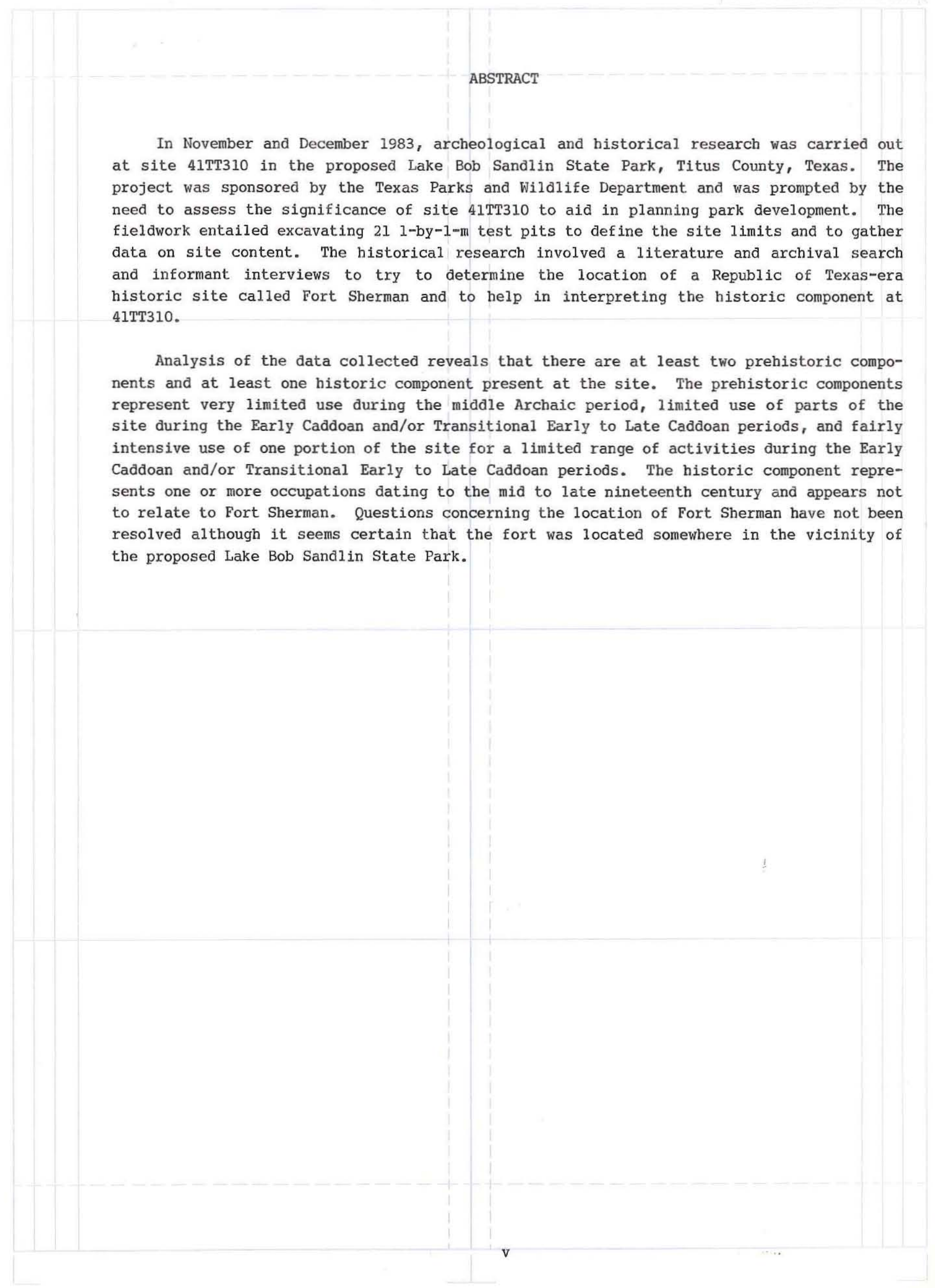




\section{ACKNOWLEDGMENTS}

Numerous people assisted in the completion of this project. Mr. Ron Ralph, Staff Archeologist at the Texas Parks and Wildlife Department, aided in the prefield planning by providing data from his survey and machine testing of 41TT310. During the fieldwork phase, he served as backhoe operator and helped interview local residents.

The archival research, analysis of historic artifacts, and reporting of the historic component at 41 TT310 have been provided by Dr. Kathleen Gilmore (Co-Principal Investigator), assisted by Nancy Reese, Cecily Pegues, and Bonnie Yates, all of the Institute of Applied Sciences at North Texas State University. Other personnel at the Institute who have participated are Lisa Dunnam, who managed the word processor, and Gerald Blow, who rendered Figures 2, 3, and 8.

The test excavations at 41 TT310 were carried out from November 14 through November 22, 1983, by Daniel J. Prikryl (Project Archeologist) and a capable crew consisting of Robert F. Scott, IV, Mary Standifer, and Sandra Hannum Price. Laboratory processing and cataloguing of artifacts was accomplished by Kerza Prewitt and Linda Nance Foster. Ms. Foster also typed the report and assisted in its editing. Figures 1, 4, 6, 9, and 10 were drafted by Sandra Hannum Price, and Linda Battles-Herron illustrated the prehistoric artifacts. Elton R. Prewitt aided in evaluating the lithic artifacts.

The sections of the report relating to the historic component at 41 TT310 were written by Dr. Gilmore and Ms. Reese. The other portions of the report were written by Mr. Prikryl except Chapter 5 which was co-authored by $\mathrm{Mr}$. Fields and Mr. Prikryl. Mr. Fields also edited the report.

Finally, all persons interviewed in conducting the historical research were most helpful. Especially helpful and gracious were Virginia and Jim McBride. 


\section{PROJECT DESCRIPTION}

The 641-acre proposed Lake Bob Sandlin State Park is in the southwestern part of Titus County approximately $4.8 \mathrm{~km}$ south-southwest of Monticello, Texas. The park is situated on the north shore of Lake Bob Sandlin with FM 21 serving as the park's western boundary (Fig. 1). The Texas Parks and Wildlife Department (TPWD) plans to develop park facilities for day use, overnight camping, and administration. Recreational oppportunities will include boating, fishing, swimming, picknicking, camping, and nature study.

In August 1983, TPWD archeologists conducted archeological survey and testing in the southwestern portion of the proposed park (Texas Parks and Wildlife Department 1983:14). This area was given first priority as it would be the location of the initial park development and because a Republic of Texas-era historic site called Fort Sherman was thought to be located somewhere in this vicinity (Sullivan n.d.:39).

The TPWD archeologists relocated sites 41TT205, a prehistoric lithic scatter, and 41TT206, a small late nineteenth-century Anglo-American cemetery, which had been previously recorded during Southern Methodist University's survey of the Lake Bob Sandlin project area (Sullivan n.d.:37). Three backhoe trenches and two motor grader cuts were excavated at 41TT205 by the TPWD personnel; these tests yielded only limited amounts of cultural materials. This site will be monitored during the construction of park facilities, and a protective fence will be placed around the cemetery at 41TT206.

Other motor grader cuts excavated 200 to $300 \mathrm{~m}$ northwest and west of 41 TT205 revealed a previously unknown site, 41TT310. It is on the partially cleared upland margin north of Big Cypress Creek and west of an intermittent creek. According to a local informant (Timothy Moore, personal communication 1983), a spring lies downslope northeast of the site but is now submerged by Lake Bob Sandlin. Materials uncovered at 41 TT310 by TPWD personnel included historic artifacts thought to date from the mid to late nineteenth century and prehistoric Caddoan sherds. The initial work by the TPWD staff suggested that stratified deposits might be present at $41 \mathrm{TT} 310$ and that some of the historic artifacts could date as early as the time of Fort Sherman.

Since the originally proposed park development would impact the eastern portion of the site, additional investigations were needed to assess the site before decisions on park development could proceed. In November 1983, Prewitt and Associates, Inc. entered into a contractual agreement with the TPWD to test site 41 TT310 and conduct an archival search aimed at determining whether or not the site is the location of Fort Sherman. The specific goals of the testing were to (1) define the eastern boundary of the site, and (2) provide data that would allow the significance of the eastern and northern parts of the site to be assessed. Prewitt and Associates, Inc. subcontracted the literature and records search on Fort Sherman to the Institute of Applied Sciences, North Texas State University.

The following chapters present a comprehensive report of investigations at 41 TT310. Chapter 2 describes the environmental setting while Chapter 3 summarizes the previous archeological investigations undertaken in the area, discusses the current chronological framework, and reviews the history of the project area. Chapter 4 details the aims and methods of the investigations. The data gathered from the excavations and the archival research are described and interpreted in Chapter 5. Chapter 6 summarizes the investigations, discusses the significance of the site, and provides recommendations for park development. 
Figure I

ARCHEOLOGICAL TESTING AT 4ITT3IO

LAKE BOB SANDLIN STATE PARK

TITUS COUNTY, TEXAS

PROJECT LOCATION MAP

n

FIGURE REDACTED

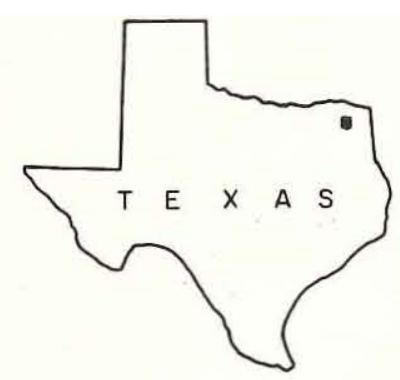

1
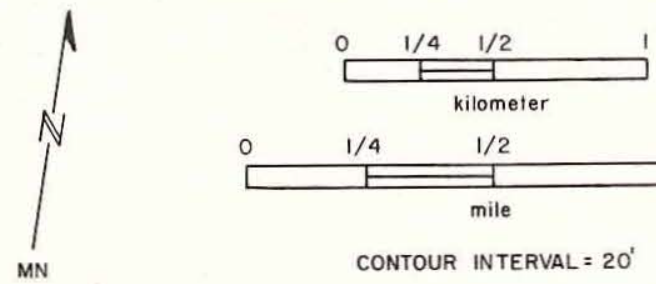

kilometer

0

$1 / 4$

$1 / 2$

mile

CONTOUR INTERVAL $=20^{\circ}$ 


\section{ENVIRONMENTAL BACKGROUND}

Northeast Texas is within the Gulf Coastal Plain, a wide, gently undulating physiographic zone bordering the Gulf of Mexico (Fisher 1965:24). Streams generally flow eastward and southeastward across the Coastal Plain through a landscape of low rolling hills and prairies. Subsurface geological formations, which dip toward the Gulf of Mexico, occasionally surface to form landward-facing cuestas. One of these cuestas, the Weches Ironstone Hills, is the major topographic feature in the region (Fisher 1965:24). Located approximately $32 \mathrm{~km}$ south of the project area, this cuesta formed by virtue of the resistant nature of the iron in the Weches Formation (Fenneman 1938:110).

The project area lies at the upper end of Big Cypress Creek, a drainage system that is bounded on the south by the Sabine River Basin and on the north by the Sulphur River Basin. The Cypress Basin encompasses an approximately $9500-\mathrm{km}^{2}$ area that includes portions of northeastern Texas, northwestern Louisiana, and the extreme southwestern corner of Arkansas (Thurmond 1981:2). Over its 120-km length, Big Cypress Creek undergoes two name changes -Big Cypress Bayou and Twelve Mile Bayou -- before emptying into the Red River at Shreveport.

The subsurface geology in the project vicinity consists of an undifferentiated sequence of alternating sands, silts, clays, and lignites that form the Eocene Wilcox Group (Fisher 1965:30). Sandy loam and loamy sand surface soils which are heavily leached and eroded cover argillic subsoils in the dissected uplands (McCormick 1973b:19). The Quaternary alluvium on the floodplains and terraces adjacent to Big Cypress Creek consists of mixed clay, sand, and gravels with fine sandy loam surface soils above clay and clay loam subsoils (Henry and Basciano 1979:map sheet 6). Prior to the floodplain's inundation by Lake Bob Sandlin, gravel deposits containing ferruginous sandstone, silicified wood, quartzite, chert, and siltstone were noted on the terraces and in the Big Cypress Creek streambed (Flaigg 1982:8). Silicified wood outcrops in the local Wilcox Group while glauconite and ferruginous sandstone are common in the Weches Formation (Fisher 1965:327-328).

The local climate has been classified as humid and moist (Thornthwaite 1948). Summers are hot and sometimes subject to drought, and the generally mild winters are punctuated by blasts of cold polar air. These polar air masses interact with moist tropical air from the Gulf of Mexico to produce rainfall in the fall, winter, and spring (Texas Water Development Board 1977:121). Other rainfall which contributes to the 110-cm yearly average comes from local thunderstorms which occur mainly in the summer.

The project area is situated within Blair's (1950:98-99) Austroriparian biotic province. It lies near the boundary of the East Texas Pineywoods and the Post Oak Savannah/ Woodland vegetation regions (Texas Parks and Wildlife Department 1983:10). Loblolly pines and various oaks, including white, red, and post, dominate the project area with other common trees including hickory, sweetgum, hackberry, dogwood, and elm (Texas Parks and Wildlife Department 1983:10-11; Sullivan n.d.:3). Understory in wooded areas includes greenbriar, red buckeye, dewberry, and French mulberry. Coastal bermudagrass is now predominant in areas formerly cleared for cultivation. 
Fauna in the project area should include many of the 47 species of mammals, 39 species of reptiles, and 17 species of amphibians listed under Blair's (1950:99) Austroriparian province. Wildlife which has been noted at the proposed park site include whitetail deer, gophers, nutrias, armadillos, three-toed box turtles, and southern leopard frogs (Texas Parks and Wildlife Department 1983:11). 


\section{CHAPTER 3}

ARCHEOLOGICAL AND HISTORICAL BACKGROUND

$\underline{\text { Native Culture History }}$

Prehistoric

The first comprehensive ordering of the cultural sequence of Northeast Texas was presented by Suhm et al. (1954). This classification recognized four periods: Paleo-American (now called Paleoindian), Archaic, Neo-American (now called Late Prehistoric or Caddo), and Historic. This general outline remains intact with the only change being Story's recent (1981) introduction of an additional period, Early Ceramic, for the transition from the Archaic to the Late Prehistoric.

The earliest period, Paleoindian, is represented in Northeast Texas by isolated finds of finely made fluted and lanceolate projectile points with Plainview, San Patrice, Scottsbluff, and Dalton being the most frequent types. No discrete Paleoindian components have been excavated in the region. The available evidence suggests that population densities in Northeast Texas were very low during the Paleoindian period and that groups were very small and highly mobile, operating in ill-defined territories (Story 1981:143). To date there is no clear evidence in Northeast Texas of Paleoindian artifacts associated with the remains of Pleistocene megafauna (Shafer 1977). The subsistence pattern was most likely a generalized hunting and gathering economy.

The Archaic period began at roughly 8000 B.P. (B.P. = years before present calculated from A.D. 1950) and terminated at approximately 2150 B.P. It is characterized by a change from fluted and lanceolate projectile points to stemmed points. Johnson's (1962) report on the Yarbrough and Miller sites, in which he defines the La Harpe Aspect, constitutes the major effort to organize the Archaic period in Northeast Texas. Johnson sees the La Harpe Aspect as encompassing a large geographical area on the western edge of the eastern woodlands extending from east-central Oklahoma to near Houston, Texas. On the basis of artifact types, he divides this region into northern, central, and southern parts. The central part, which is pertinent to this report, includes southeastern Oklahoma and northeastern Texas. Traits unique to the central region are gouges, full-grooved axes, numerous pitted manos and grinding slabs, and a scarcity of polished stone tools. Traits which are shared with the northern division are double-bitted axes, triangular and oval knives, small stemmed drills, and triangular end scrapers (Johnson 1962:269). In terms of temporally diagnostic artifacts, Johnson (1962:268) recognizes expanding stem dart points, such as Yarbrough, as indicative of the early part of the La Harpe Aspect. Later, contracting stem Gary dart points become predominant before the appearance of plain, crude pottery which is considered diagnostic of the very late part of the La Harpe Aspect.

The tool types of the La Harpe Aspect are indicative of a generalized hunting and gathering economy. Social groups may have ranged in size from extended families to bands. These presumably nomadic groups may have operated on a seasonal round within territories which probably became better defined through time. Group size probably fluctuated depending on the availability of food resources (Story 1981:143-145). 
By the late Archaic, sites are larger and more numerous and yield greater quantities of artifacts. Story (1981:144) suggests that these changes reflect changes in subsistence practices, technological innovations, reduced group mobility, more favorable environmental conditions, and more effective exploitation of the environment through experience.

Around 2150 B.P., the first ceramics appear in East Texas with a grog- and sometimes bone-tempered ware, called Williams Plain, and a plain sandy paste ware being common. Less frequently found are Marksville and Troyville types from the Lower Mississippi Valley. These ceramics are considered diagnostic of the Early Ceramic period (Story 1981:145-147), which is equivalent to what Johnson (1962:269) calls the terminal La Harpe Aspect. It appears that, other than the introduction of pottery, the artifact assemblage of the Early Ceramic is the same as that of the late Archaic (Story 1981:146). Currently there is no archeological evidence of horticulture during this period (Story 1981:146).

In addition to the introduction of pottery, the other prominent feature of the Early Ceramic period is the occurrence of a small number of burial mounds which date from approximately 2050 to 1550 B.P. These mounds contain some Marksville pottery along with small amounts of grave goods which suggest that prehistoric peoples in East Texas were involved in the Hopewellian trade network. Story (1981:146-147) sees these mounds as probably reflecting "new kinds of social relationships including more sharply defined group identities and specialized roles, which were probably ranked and had important control over exchange." None of these early mounds are known in the Titus County vicinity, but they are found eastward in northwestern Louisiana and southwestern Arkansas and also southward in the central part of East Texas on the Angelina, Neches, and Sabine rivers.

The Late Prehistoric period in Northeast Texas extends from about 1150 B.P. to the time of sustained European contact at approximately 250 B.P. This period is marked by a number of innovations. The bow and arrow is introduced and surely must have improved hunting efficiency. Decorated Caddoan pottery and numerous artificial mounds appear in the area. To the south, there is the first evidence of corn at the George C. Davis Site (41CE19) by 1170 B.P. (Story 1981:149). A more settled lifeway is demonstrated in the Cypress Creek area by the more intensive use of fewer sites during the Caddoan periods (Thurmond 1981:409). Thurmond's (1981:459) table of component frequency relative to the length of chronological units indicates a population increase in Caddoan times.

Stratified social structure is suggested as some of the manmade mounds were utilized in ritual burial of individuals who were often accompanied by grave goods and retainers. Ritual behavior is further demonstrated by the construction of other mounds which apparently served as platforms for ceremonial structures or, in the case of the Whelan Complex, covered burned structures (Davis 1970:47). Major mound complexes dating to the early half of the Late Prehistoric in the immediate project vicinity are the Keith (4.1TT11) and Hale (41TT12) sites. These could have served as focal points of settlement systems which were made up of large villages, hamlets, and farmsteads. No late Whelan Complex mounds have been found in the vicinity, but late cemeteries such as Tuck Carpenter (41CP5) and Alex Justiss (41TT13) are evidence of sustained Late Prehistoric Caddoan occupation.

The Late Prehistoric period also has been termed the Neo-American (Suhm et al. 1954) and Caddo (Davis 1970). On the basis of the University of Texas Work Projects Administration excavations of the 1930s, Krieger (1946) defined two aspects, Gibson and Fulton, within this period and various subdivisions called foci. Davis (1970) later divided this period into five parts with his Caddo I and II being equivalent to the earlier Gibson 
Aspect while Caddo III and IV equated with the later Fulton Aspect. Sites or components including native materials in association with European or Euro-American artifacts are placed in Davis' Caddo V period. Krieger's previous chronology had not dealt with sites of this era.

The most recent and geographically relevant discussion of the chronology of the Late Prehistoric period is found in Thurmond's (1981:91-93) thesis. He utilizes the term "Caddoan" rather than "Late Prehistoric" and divides the chronology of the Western Cypress Basin into three parts: Early Caddoan, Transitional Early to Late Caddoan, and Late Caddoan. This chronology primarily relies on ceramics for temporal indicators with arrow points being useful diagnostics only during the Late Caddoan.

Early Caddoan components are recognized by the occurrence of plain, incised, punctated, and fingernail-impressed ceramics. Types generally seen in Early Caddoan assemblages are Hickory Fine Engraved, Carmel Engraved, Crockett Curvilinear Incised, and Pennington Punctated-Incised. Red River style pipe fragments also are considered as diagnostic of the Early Caddoan.

Thurmond divides the Early Caddoan into two parts with Period 1, which dates from 1150 to 750 B.P., being characterized by pottery types such as Davis Incised, Holly Fine Engraved, Kiam Incised, Spiro Engraved, and Weches Fingnail-Impressed. Coles Creek Incised and other Coles Creek types also are included as diagnostics. The Early Caddoan Period 2 ceramic types are Canton Incised, Haley Engraved, Maxy Noded Redware, Sanders Engraved, and Sanders Plain. Temporally, Period 2 is thought to occur at 750 to 500 B.P.

Thurmond (1981:92) postulates a brief Transitional Early to Late Caddoan period from 550 to 450 B.P. in the western part of the Cypress Basin. Ceramic types are a combination of Early Caddoan Period 2 and later Whelan Phase types.

The Late Caddoan period is divided into two phases -- Whelan (450-350 B.P.) and Titus (350-250 B.P.). Both phases include pottery of the Bullard Brushed and Maydelle Incised types with brushed sherds being especially prevalent. Elbow and biconical pipes are also typical in Late Caddoan components. During the Whelan Phase, Ripley Engraved and Pease Brushed-Incised pottery types are seen along with Scallorn and Perdiz arrow points. A wide variety of pottery types, including Bailey Engraved, Harleton Applique, Karnack BrushedIncised, La Rue Neck Banded, Ripley Engraved, Taylor Engraved, and Wilder Engraved, are diagnostic of the Titus Phase. Arrow points associated with these ceramics are the Bassett, Maud, Talco, and Reed types.

\section{Historic}

In early historic times, East Texas was occupied by two major groups, often called confederacies. The Kadohadacho occupied the Red River area near Texarkana, Texas, and the Hasinai were concentrated along the Neches and Angelina rivers south of Tyler, Texas (Swanton 1942; Griffith 1954; Newcomb 1961). Continuity between Late Prehistoric cultures in East Texas and the Hasinai has been demonstrated by several investigators (Woodall 1969, 1972; Anderson 1972; Gilmore 1973; Anderson et al. 1974; Wyckoff and Baugh 1980). 
While historic accounts of the native peoples north and south of the project area exist, information about the local groups on Cypress Creek is 1acking. If Castenadas' (1936) interpretation of the route of the De Soto Expedition is correct, the earliest possible European contact with native peoples in the project vicinity may have occurred in 1542 during the wanderings of these explorers. It should be noted that there is disagreement about the Expedition's route, and Swanton (1939), for example, shows it as being much farther south. Because the most direct route between the Hasinai and Kadohadacho confederacies crosses the Cypress Basin below Caddo Lake (Thurmond 1981:448), it appears that most if not all early travelers by-passed the western half of the Cypress Creek Basin.

No historic Indian sites have been scientifically excavated within the Cypress Creek Basin. Thurmond (1981:131) describes reports of burials with European glass beads and Titus Phase ceramics being excavated by pothunters at the Tracy Site, 41CP71. An historic Indian site dating to the 1830 s was also recorded by Cliff et al. (1974) during the survey of Lake Swauano. Unfortunately, the site was neither tested nor excavated. Further afield, the Gilbert Site (Jelks 1967) near Lake Fork Reservoir and the Pearson Site (Duffield and Jelks 1961) at Lake Tawakoni have been excavated. These sites, located about 72 and $97 \mathrm{~km}$ west-southwest of the project area, have been placed within the Norteno Focus, a unit that represents the remains of the Wichita tribes which moved southward from Oklahoma into northern Texas in historic times.

Based on the lack of historic accounts and historic archeological remains of native peoples in the western part of the Cypress Creek drainage, it appears possible that the occupation of this area declined near the end of the Titus Phase (Davis 1970:50). Thurmond (1981:447-448), on the other hand, believes that his Late Prehistoric Cypress Cluster, which is structurally analogous to the Hasinai and Kadohadacho confederacies, persisted into historic times and simply went unrecognized because European travelers by-passed the area.

\section{Review of Anglo-American History}

The early Anglo-American history of the area near the proposed Lake Bob Sandlin State Park appears to be partly the history of efforts to make the region safe for Anglo settlement. Indian troubles continued to plague this part of Texas through the 1830s. Under orders from General Dyer, Captain W. B. Stout raised a company of 38 men (Gulick and Allen 1924:273) and in 1838 set out for the Cypress Creek area. Before Stout could get there, a local resident, Joseph Harris, was killed by Indians early on the morning of December 5 . Stout arrived in the evening and buried him. The settlement was alarmed and "Blundle [sic], Harris family and the whole settlement convened on the Cypress neare [sic] the Cherokee Crossing under the protection of Captain Stout, where a fort was built called Fort Sherman--[sic] There are $[\underline{\mathrm{sic}}] 8$ or 9 families here" (Gulick and Allen 1924:274). Pierce (1969:158) states that the fort was named for Lt. Col. Sidney Sherman, commander of the left wing of the Texas Army at San Jacinto. Pierce (1969:19) notes a military camp, called Blundell Camp, on or near the farm of William Blundell in the Cypress Creek area. He further notes (Pierce 1969:157) that Stout's men may have worked on Fort Sherman while at the Blundell Camp and suggests that Stout's company stayed at an encampment called Camp Sherman during a part of the summer of 1840, doubtless near Fort Sherman. After establishing Fort Sherman, Stout left 15 men and went to the Sabine. The Indian wars on this frontier were terminated in December 1841 (Gulick and Allen 1924:274). 
Stout almost bad a small mutiny while at Fort Sherman. His soldiers had served the three months for which they had enlisted and were prepared to go home, but the captain forbade it, acting on the orders from General Dyer that two tours of duty were required if the country needed it. Stout was supported by Lt. John M. Watson and two others. The privates in the company were paid $\$ 25$ per month, and the captain was paid $\$ 75$ per month (Texas State Archives 1840). David Patten, D. L. Ross, Ezeriah (?) Brackein, and James Bailey were discharged by Stout on August 2, 1840 (Texas State Archives 1840). J. H. Blundell was discharged September 10, 1840 (Pierce 1969:224).

With the alleviation of Indian troubles, other families began to move into the area. Land was selling at a low price during these years, about 25 cents per acre (Pierce 1932: 30). A survey of 320 acres was made for Andrew Coots, assignee of Celia Coots, in 1841 (General Land Office 1841). This property was "situated near Fort Sherman on the North side of big Cypress" and apparently lies just west of the proposed Lake Bob Sandlin State Park (Fig. 2). A plotting of this survey does not close, which is noted in pencil on the survey field notes (General Land office 1841). In 1843, 640 acres lying on both sides of Cypress Creek "where the Cherokee Trace" (Russell 1967:42) crosses the Cypress were surveyed for Hugh Allen (see Fig. 2). These families were probably in the area before the surveys were made. The Coots family had come to the area by 1838 as David and George Coots were chain carriers in the 1838 Joseph Reed Survey. Fort Sherman probably was visible at the time of the 1841 Celia Coots Survey and also when a second survey was made for her in 1842 on lands about $3 \mathrm{~km}$ north of the original survey (see Fig. 2). The field notes of this survey state that the surveyed lands lie "N of Big Cypress and $W$ of Ft. Sherman" (General Land Office 1842).

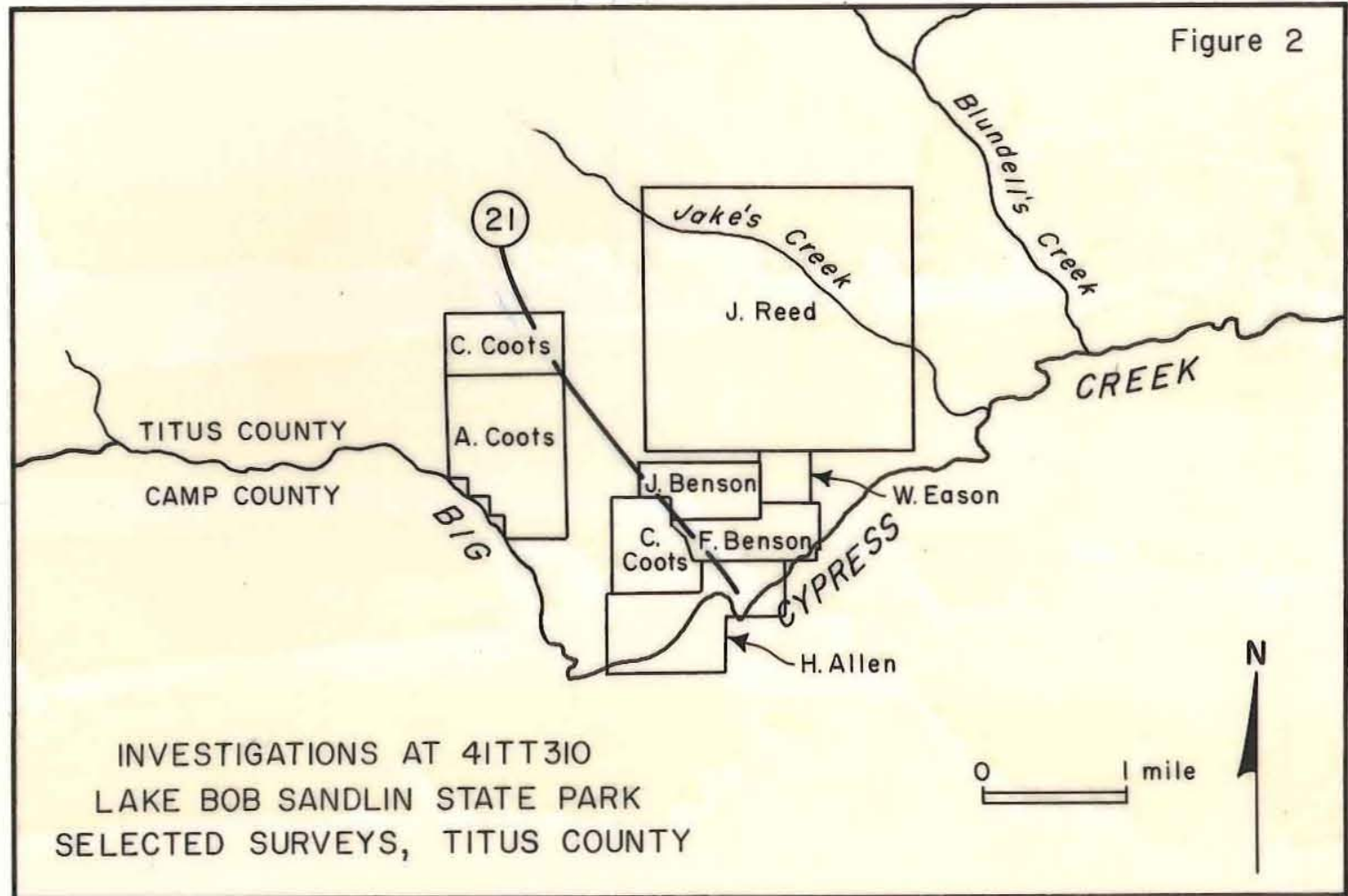


Some evidence of Fort Sherman was still visible in 1846 when John P. Gaines observed it on his "march" to Mexico with the First Regiment of the Kentucky Volunteer Cavalry (Winfrey 1963:20). He noted in his diary (Winfrey 1963:28),". . Old Fort Sherman built many years ago as a protection against the Indians, gone to decay, and a handsome peach orchard grown up on its ruins." Philosophically he added, "I wish society was so constituted that we could have a peach orchard in lieu of every fortification in the universe" (Winfrey 1963:28).

Other early settlers in the Lake Bob Sandlin State Park area were Jesse and F. W. (Frank Wiley) Benson, two brothers who, as family history relates, came from Tennessee or Kentucky before the Civil War. Both patented land (see Fig. 2). Frank W. Benson's patent was dated February 11, 1858 (Mount Pleasant Public Library). A survey was made on February 17, 1854, and on that same day Frank W. appeared before the court to swear he had settled on vacant land (General Land Office 1854a, 1854b).

Lewis Benson (personal communication 1983), born in 1897 and a grandson of Jesse Benson, related that Jesse Benson had nine children and that Frank $W$. Benson had two daughters. Frank, he said, had a two-story log house near the Miller Cemetery which 1ies just south of site 41 TT310 (Fig. 3; this cemetery is recorded as 41TT206). Jesse married Mary Jane Eason, no doubt related to William Eason, who patented a survey east and north of the Benson surveys.

The story is told (Russell 1965:101; Lewis Benson, personal communication 1983) that Frank W. Benson had money secreted on his place, which was south of his brother's farm (see Figs. 2 and 3). On an occasion when he was away from home, three men tied up the people in the house including his family and several Negro slaves. When he returned, the men seized him and demanded to know where the money was hidden. Russell (1965:101) relates that the money was bidden in a grave in the cemetery; however, Lewis Benson (personal communication 1983) says that Russell's source, Charles Brantley, was a "tale spinner" and that the money was hidden in the logs in the house. Furthermore, it is doubtful the cemetery was in existence at that time. Frank Benson, realizing that his life and the lives of the others were in danger, went upstairs to get the money with the robbers behind him. Spotting an axe which bad been left at the head of the stairs, Frank W. suddenly grabbed the implement and split open the head of the bandit nearest him. The bandits left, apparently without the money.

On August 2, 1858, F. W. Benson deeded 230 of his 273.7 acres to Julia E. Benson (Titus County Deed Records 17:65). Julia may have been his wife or a daughter, although there is no Julia Benson listed in the Jesse Benson family tree. Jesse Benson is listed on the Civil War muster rolls (Russell 1965:80) from Titus County, but F. W. Benson is not. It is probable, therefore, that F. W. left before the Civil War. Family tradition has it that he and his family moved to Oklahoma.

The next transactions recorded on the F. W. Benson Survey are those of S. H. Miller in July 1899. S. H. (Sam) Miller was the son of T. H. and Mary Elizabeth Miller. No records have been found of transactions during the period between 1858 and 1899, and it is not known how T. H. Miller came into possession of the land. Sam inherited a share of one-half interest in 273.7 acres when his father died in 1893 , and in 1899 he began buying the interest of all the heirs. These heirs, in addition to Mary Elizabeth who inherited onehalf interest, included: Levi, child of T. H. Miller and his first wife; Sally Dickson (Garretson), a daughter by Mary Elizabeth's first marriage; Louis; Belle (Maxey); Linda 
FIGURE 3 REDACTED 
(Stafford); Henderson; and Clara (Jones) (Titus County Deed Record 216:263-264). In 1918, S. H. Miller and his wife Emma L. sold the 273.7 acres to H. W., J. C., and B. W. Pickens (Titus County Deed Record 39:126).

The cemetery (41TT206) which is on the F. W. Benson Survey and just south of $41 T T 310$ is known as the Miller Cemetery and the Fort Sherman Cemetery (Mount Pleasant Public Library). Three gravestones are all that remain: (1) T. H. Miller, buried on 4-21-1893; (2) Mary E. Miller, 3-13-1834 to 2-3-1907, Being 72 years, 10 months and 18 days of age; and (3) J. F. Coston, C S A Vet (a recent marker). Titus County Cemetery Records on file at the Public Library, Mount Pleasant, Texas, report a fourth stone marked "Miller Baby," but it was not observed in 1983. Sam Miller put concrete on the graves of his mother and father and repaired or replaced the gravestones in the mid 1940s (Lewis Benson, personal communication 1983). Benson family tradition relates that Jesse Benson is buried in this cemetery. Lewis Benson (personal communication 1983) reports witnessing at least three burials there, one of which was that of Henry Britt.

J. F. Coston was the grandfather of A. P. Parr (born 1901), a local resident. Parr (personal communication 1983) remembers playing in the cemetery area when he was 10 or 11 years old. The cemetery was not fenced, and the grave markers were of "petrified rock" with no names. He also remembers the Miller rent house as being near a barn and a well, perhaps just northwest of 41 TT310 (see Fig. 3). Parr (personal comunication 1983) reports that this house was old when he was a boy.

It is unknown how many graves are actually in the cemetery in addition to those that are marked. Although Jesse Benson is reportedly buried there, it is doubtful that burials were begun before the Civil War. After it was started, the cemetery served as a community cemetery (Lewis Benson, personal communication 1983), but none of the deeds that were examined set aside any property for that purpose.

With the 1918 sale of the 273.7 acres of the F. W. Benson Survey by S. H. Miller to H. W., J. C., and B. W. Pickens, it was H. W. (Waterson) Pickens who farmed the tract. He was the father of Virginia P. McBride and three other girls. His motber, leaving her husband in Tennessee, came to Texas to join her twin brother, T. Williams. Pickens, according to his daughter Virginia Pickens McBride (personal communication 1983), was one of the first farmers in the area to get away from the single crop cotton into crop rotation. He was born in 1887 and died in 1971. He built the rock house which lies northwest of 41 TT310 (see Fig. 3) in 1937. Virginia McBridge (personal communication 1983) remembers that the Miller house was near the rock house and that both structures were much farther from the road than they are now. Mr. Pickens reportedly' plowed up a "bucket full of arrow heads" on his property, which he sent to East Texas State University at Commerce because his daughter was in school there.

\section{Previous Investigations}

The earliest known archeological work in the immediate vicinity of the project area other than the artifact collecting done by Mr. Pickens was a part of the 1930s University of Texas program directed by J. E. Pierce. These investigations were oriented primarily toward the excavation of Caddoan mounds and cemeteries in order to gain museum specimens. In total, 18 cemeteries, 4 mound sites, and 8 middens were tested and/or excavated within the portion of the Cypress Creek drainage in Texas. One of those sites tested in a search 
for Caddoan burials was the L. A. Hale Farm Site, 41TT12, which is just $9 \mathrm{~km}$ north of the project area (Jackson 1934). The site consists of two manmade mounds, three other mounds which appear to be natural knolls capped by occupational debris, a sixth mound of unknown nature, and at least one borrow pit. Of the six components present, the primary one appears to be an Early Caddoan Period 1 component which produced the mounds and much of the occupational debris (Thurmond 1981:352-353).

Despite the inadequacies of much of the 1930s work in comparison to current standards, Thurmond (1981:52) notes that it produced the largest body of existing data from the Cypress Creek Basin. Goldschmidt (1935) used some of this data to write an early descriptive article on the archeology of Titus County, and Krieger (1946) later relied on the data to aid in his definitions of the Gibson and Fulton aspects and their foci.

No fieldwork occurred in the Titus County area in the 1940s, but in the 1950s major archeological salvage was undertaken at Ferrell's Bridge Reservoir, now called Lake $0^{\prime}$ the Pines. Located on Cypress Creek approximately $50 \mathrm{~km}$ downstream from 41TT310, this reservoir was surveyed first by the River Basin Surveys (Miller et al. 1951) and later by W. A. Davis of the University of Texas. Emphasis was placed on testing and excavation of sites rather than on intensively surveying the entire reservoir area. These excavations provided data on the local chronology and on the function of components at seven sites. In particular, the excavations are noteworthy for defining the Caddoan Whelan Complex (Davis 1958).

In 1967 the Texas Archeological Society held its annual field school in Camp County at the Harold Williams Site, 41CP10 (Woodall 1967). These excavations produced data on the little known Transitional Caddoan period (Thurmond 1981:73). The site had also previously yielded a Titus Phase cemetery. This cemetery is but one of 13 Caddoan cemeteries excavated in the project region by Robert Turner and other amateur archeologists. The results of the excavation of one of these cemetery sites, 41CP5, have been published (Turner 1978). The cemetery at 41 CP5 contained 44 graves with funerary offerings that date to the Titus Phase. By analyzing burial orientations and comparing them to the yearly positions of the sun at sunset, Turner $(1978: 49-52)$ was able to suggest that most of the burials occurred during late winter.

Most of the recent archeological work in the region has been conducted by Southern Methodist. University (SMU) and the Texas Building Commission for several reservoir projects, all of which are within $25 \mathrm{~km}$ of 41TT310. These lakes include Lake Bob Sandlin, Lake Swauano, Lake Cypress Springs, and Lake Monticello. Work at Lake Swauano (McCormick 1973a; Cliff et al. 1974) and Lake Cypress Springs (Hsu et al. 1969) was restricted to survey. Although further work was recommended at each lake area, none was carried out.

An archeological reconnaissance of the combined Lake Bob Sandlin and Lake Monticello areas was conducted by Hsu (1969) for the Texas State Building Commission and the Texas Water Development Board. Additional survey at Lake Monticello by McCormick (1973b) of SMU attempted to place the sites within detailed schemes of site types and environmental settings. Six of the 68 sites at Lake Monticello were later tested (McCormick 1974), and preservation of 41 TT12 was secured through acquisition of a 99-year lease of the site by SMU. Of those sites tested, the major efforts focused on 41TT28 and 41TT132. In reviewing McCormick's findings at 41TT28, Thurmond (1981:359) sees a predominant Early Caddoan component which may relate to that at 41TT12. At $41 \mathrm{TT} 132$ he notes evidence of a small Late Caddoan settlement and more-limited occupation during four or five other periods (Thurmond 1981:383). 
SMU's survey of Lake Bob Sandlin (Sullivan n.d.) recorded 106 sites. As with the work at Lake Monticello, the surveyors placed each site within a classification of environmental settings and functional site types to try to discern settlement patterns. Only seven sites at Lake Bob Sandlin were tested by SMU, with the results demonstrating the difficulties of projecting site function using survey data (e.g., Sullivan n.d.:64, 93). No recommendations for further testing or mitigation were made in this report.

Additional work at Lake Bob Sandlin was conducted by the University of Texas at Austin Archeological Field School at the Benson's Crossing Site, 41TT110. These excavations focused on the excavation of a Caddoan midden dating from the Early Caddoan Period 2 to the Whelan Phase (Thurmond 1981:377; Flaigg 1982:189). Approximately 65\% of the midden was removed in a contiguous block excavation. Three smaller units at 41TT110 yielded Archaic materials; a large amount of burned rocks in one of these units was interpreted as a discard pile, presumably from one or more hearths (Thurmond 1981:371).

Although the ceramic analysis of the Benson's Crossing materials has not been completed, the lithic artifacts are the subject of a recent master's thesis (Flaigg 1982). Flaigg concluded that: (1) the lithic tool assemblage shows little variety and changes very little through time; (2) most lithic materials utilized at the site are of local origin; (3) no stratigraphy is present, but the Caddoan materials cluster horizontally; and (4) lithic densities and material types are not useful in differentiating between Archaic and Caddoan occupations.

Flaigg (1982:188) sees a light Paleoindian occupation at 41 TT110 being followed by an Archaic occupation which featured a wider variety of tool types and which may reflect a more generalized economy and/or more intensive utilization of the site during the Archaic. He hypothesizes that because of the low lithic densities and the limited structural evidence, the Caddoan occupation was a farmstead or small hamlet utilized by an extended family or several small families.

The Texas Department of Highways and Public Transportation (TDHPT) recently has issued reports of excavations at two Titus County sites, 41TT13 (Bel1 1981) and 41TT108 (Young 1981). The report on 41 TT13 describes a limited amount of Archaic and Caddoan materials found during testing by TDHPT personnel along with a larger volume of data derived from amateur excavation of a Titus Phase cemetery yielding 26 burials and numerous grave goods.

The excavations at 41 TT108 produced a large volume of lithic materials. Although the deposits have been churned by burrowing rodents, Young (1981) does present some evidence of isolatable components through changes in projectile point styles. The earliest component mostly features Yarbrough points and is one of the few examples of an identified middle Archaic component in the area. Young (1981) defines the second component by the predominance of large Gary dart points. Small Gary dart points, arrow points, and a ceramic collection containing Early Ceramic and Early Caddoan Period 1 types represent the third major component. The fourth component appears to be mixed as it is represented by lithic debitage and recent twentieth-century debris. 


\section{CHAPTER 4}

\section{RESEARCH STRATEGY AND TECHNIQUES}

This chapter consists of three parts. The first part summarizes what was known about site 41 TT310 prior to test excavations. The second and third sections discuss the goals of the project and the methods utilized to accomplish these objectives.

\section{Summary of Survey Information}

Site 41TT310 was recorded in August 1983 during a cultural resources survey of the southwestern portion of the proposed Lake Bob Sandlin State Park by TPWD staff archeologists. Survey techniques included surface inspection and 1/4-inch-screened shovel tests. Thirteen motor grader (MG) cuts and four backhoe trenches were excavated in and around the site area to search for features, determine the depth of deposits, and define the horizontal limits of the site (Fig. 4).

These procedures revealed that both prehistoric and historic artifacts were present and indicated that the site covered an area at least 275 by $125 \mathrm{~m}$ ** Artifacts appeared to be most numerous in the southern site area in the vicinity of MG 5A, 5B, and 5C (see Fig. 4). Cultural materials appeared to occur at depths of up to $1 \mathrm{~m}$ in some places. No cultural features were observed in the sandy loam topsoil or in the sandy clay subsoil.

The TPWD test excavations showed that the southwestern edge of the site (in the vicinity of MG 5C) had probably been removed for highway fill. Although the northwestern margin of 41TT310 was easily defined by a deeply entrenched gully, the far northern and eastern boundaries remained uncertain due to the presence of thick vegetation and the limited extent of the test excavations.

Historic materials found by the surveyors included decorated and plain whiteware and pearlware, stoneware, rusted metal fragments, cut nails, and various kinds of glass. The TPWD archeologists noted that these artifacts appeared to generally overlie the prehistoric materials, which consisted almost entirely of small undecorated potsherds. The materials recovered during this survey were judged to reflect a Caddoan occupation and a mid to late nineteenth-century Anglo-American occupation. Since it had been reported that the Republic of Texas-era Fort Sherman was supposed to be in the vicinity of the proposed Lake Bob Sandlin State Park (Sullivan n.d.:39), it was felt that the nineteenth-century component at $41 T T 310$ could possibly relate to this historic fort.

\section{Objectives of the Project}

The principal aim of this project is to assess the extent and nature of the eastern and northern portions of 41 TT310 since a number of planned park facilities, including a

*As discussed later in this report, the testing carried out by Prewitt and Associates, Inc. revealed that the site actually covers an area of some 380 by $85 \mathrm{~m}$. 
parking lot, road, comfort station, picnic tables, and trailhead, have the potential to impact those parts of the site. In addition, a literature and records search has been conducted to attempt to determine whether or not the site is the location of Fort Sherman and to assess the nature of the mid to late nineteenth-century component. The goal of these efforts has been to provide the TPWD with data which will allow them to proceed with park development without adversely affecting the cultural resources in the southwestern part of the park.

\section{Methodology}

This section discusses the methods utilized in the fieldwork and in the historical research. Topics covered under the fieldwork portion include the rationale for the placement of test pits, the excavation and recording techniques utilized, and the manner in which the artifactual materials were processed in the laboratory. The historical research section describes how the information search was conducted.

\section{LOCATION OF TEST PITS}

The technical proposal offered to the TPWD by Prewitt and Associates, Inc. stated that 22 1-by-1-m test pits would be excavated during the testing in order to: (1) obtain information from the central part of the site so that the significance of the eastern and northern site areas could be ascertained; (2) define the eastern and northern limits of the site; and (3) investigate an area west of the known site limits for the presence of Fort Sherman.

To accomplish the first task, five 1-by-1-m test pits, labeled $\mathrm{A}, \mathrm{B}, \mathrm{E}, \mathrm{F}$, and $\mathrm{Q}$, were excavated in the central part of the site in the vicinity of MG $5,5 \mathrm{~A}$, and $5 \mathrm{~B}$ (see Fig. 4). It was in this area that most of the cultural materials had been found during the survey. Test Pits $\mathrm{A}$ and $\mathrm{B}$ were contiguous as were $\mathrm{E}$ and $\mathrm{F}$.

In order to locate the eastern and far northern boundaries of the site, 14 1-by-1-m test pits (C, D, G-P, T, and U) were excavated (Fig. 5a). Twelve of these pits were placed on five transects running perpendicular to the suggested site boundary (see Fig. 4). The remaining two units ( $I$ and $U$ ) were situated to test a possibly uncultivated portion of a knollcrest and a proposed alternate parking lot area.

Two contiguous 1-by-1-m units ( $R$ and $S$ ) were placed beyond the known western edge of the site just outside of the area formerly under cultivation in order to check the possibility that historic materials associated with Fort Sherman might be located there.

In total, 21 of the proposed 22 test pits were dug. Rather than excavate the last test pit, the hilltop northwest of the creek which forms the northwestern site boundary was shovel tested to check for cultural materials on and near a proposed hiking trail. A total of five 1/4-inch-screened shovel tests on that hilltop failed to produce any artifacts. Several other 1/4-inch-screened shovel tests were excavated during the course of the fieldwork to check certain areas for the presence of cultural materials. 
Figure 4

ARCHEOLOGICAL TESTING AT 4ITT3IO.

LAKE BOB SANDLIN STATE PARK

$\underset{\text { FIGURE }}{\text { SITE }} \underset{\text { REDACTED }}{\text { MAP }}$ 
FIELD METHODS

A horizontal grid was not established at site 41TT310 during these investigations. Instead, individual test pits were laid out using the right triangle-hypotenuse method and were aligned on magnetic north with the aid of a compass.

Each unit was excavated in arbitrary $10-\mathrm{cm}$ levels with elevations being measured by line levels. All matrix was passed through 1/4-inch hardware cloth with all materials remaining in the screen, except roots, being bagged for inspection after laboratory washing.

Test pits were excavated down to the clay or sandy clay B horizon except in the cases of Test Pits B, F, N, P, Q, and S. Test Pits N, P, and Q were terminated when levels yielding no artifacts or significantly reduced artifact densities were encountered. Test Pits $B, F$, and $S$, which were contiguous with Test Pits $A, E$, and $R$, were discontinued due to time limitations. In each case, the adjacent 1-by-1-m square was excavated to the $B$ horizon.

Features that were uncovered were mapped in plan view and photographed (Fig. 5b). Additionally, features were cross sectioned, except in the case of Feature 2 where the north and west wall profiles of Test Pit U were utilized instead.

Prior to the field program, the TPWD land surveyors had produced a 2-ft-contour map of the site. The surveyors also had set four horizontal and vertical datum markers on the site and had determined the absolute elevations of these stakes. They had attempted also to relate the markers to the Texas Plane Grid System. With all of these data provided, topographic mapping by the archeologists was unnecessary. Using a transit, stadia rod, and $30-\mathrm{m}$ tape, the locations of test pits and backhoe trenches were calculated in relation to the four datums and were plotted onto the 2-ft-contour map. Likewise, the elevations of the line level nails utilized to excavate test pits were shot with the transit and computed in meters above sea level in order to provide vertical control.

Written documentation of the field investigations consists of (1) a daily journal maintained by the Project Archeologist, (2) a level report for each 10-cm level excavated in each pit, (3) a feature form for each feature uncovered, (4) a measured profile of one wall (usually the east wall) of each excavation unit, (5) photograph logs, (6) transit mapping notes, and (7) a specimen inventory. Photographs were taken of the general site area, one wall (usually the east wall) of each excavation unit, and fieldwork activities.

\section{LABORATORY PROCEDURES}

All materials collected from the surface of the site and from 1/4-inch screening of test pit matrix were washed in Austin. Numerous naturally occurring, unaltered ferruginous sandstone fragments were then sorted out and discarded. A lot number was then assigned for each provenience. Materials relating to the prehistoric occupation were labeled individually with site number and lot number in Austin by Prewitt and Associates, Inc. personnel. The historic artifacts were shipped to the subcontractor for cataloguing and analysis. All artifacts and other materials resulting from this project are curated at the Texas Archeological Research Laboratory, The University of Texas at Austin. 
Figure 5

Photographs of Excavations



a. Excavations in progress at Test Pit C.

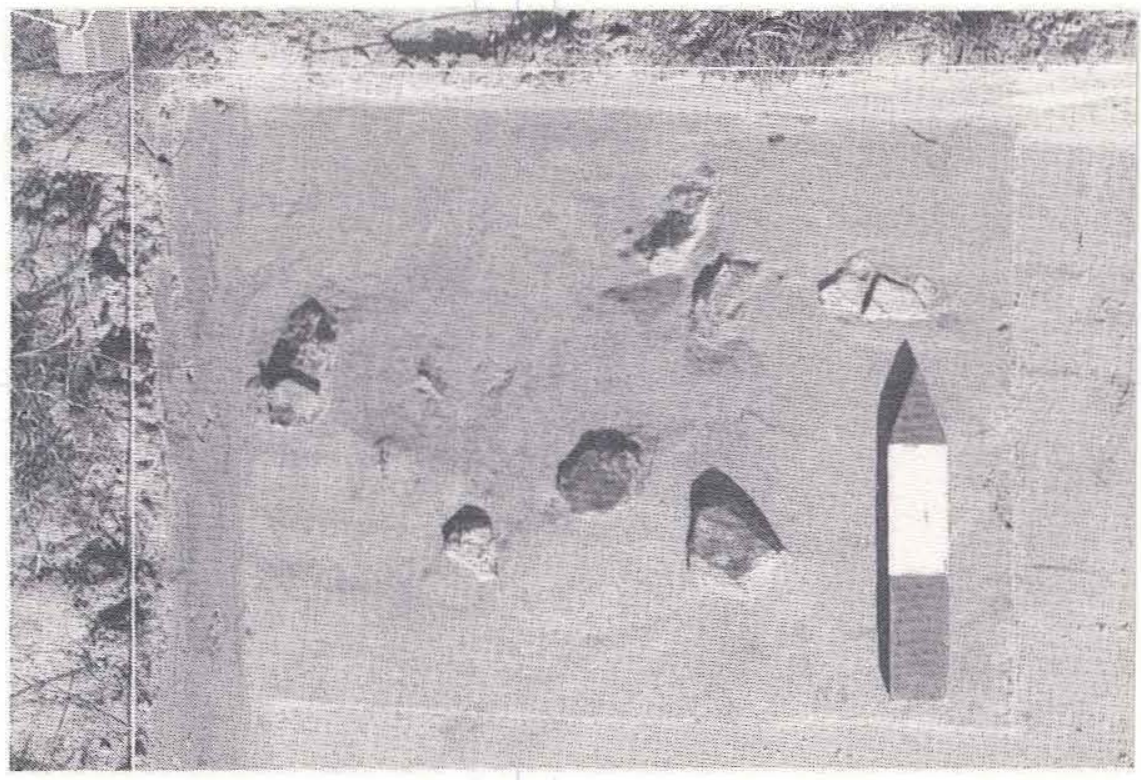

b. Plan view of Feature 1 . 
Historical Research

The historical research began with a literature search at the libraries of North Texas State University. The map collection was also searched for the location of Fort Sherman. Maps dating to 1872 show the name Fort Sherman, or 01d Fort Sherman, in southwestern Titus County near a crossing of Cypress Creek, but these maps are of such a scale that the precise location cannot be pinpointed.

Patents to deeds were obtained from the General Land Office in Austin and the Titus County Clerk's Office. The Titus County Courthouse burned in 1895, but some records were filed at Daingerfield or Clarksville before Titus County was formed in 1846. According to Lynch Harper (personal communication 1983), former County Clerk, many of these were copied for filing in the new Titus County Courthouse. Several affidavits were found at the Courthouse which helped clarify some of the land transactions.

Copies of original survey patents of the F. W. Benson Survey, the Jesse Benson Survey, and two of the Celia Coots surveys were obtained from the General Land Office. All surveys that contained metes and bounds of the property were plotted.

The Mount Pleasant Library contains a typescript of B. C. Pierce's (1932) thesis concerning Titus County and cemetery and genealogical records, some of which were useful.

The Texas State Archives were searched with the help of Michael Green, State Archivist, for information concerning Fort Sherman. Some information was found, but little that was new.

Interviews were made with persons living in the project vicinity as well as other persons thought to be knowledgeable about the area. Robert Russell, son of the recently deceased author Traylor Russell, was consulted but had no knowledge of the project area. Others interviewed are as follows: Virginia Pickens McBride, daughter of $H$. W. Pickens; Jim McBride; Timothy Moore, grandson of A. P. Parr and owner of the Fort Sherman Gunsmith Shop near the project area; A. P. Parr, grandson of J. F. Coston, a Civil War Veteran buried in the Miller Cemetery; Lynch Harper, former County Clerk and compiler of the Titus County Cemetery Records; Lewis Benson, age 86, grandson of Jesse Benson, and lawyer at the War Criminals Trials at Dachau, Germany; and Marie Benson Wilbanks, great-granddaughter of Jesse Benson. 
The test excavations resulted in the collection of 488 artifacts which consist of prehistoric ceramics and lithics along with various ceramic, glass, and metal historic artifacts. These artifacts, their distributions, and the information gained from study of the soil profiles and the one cultural feature found provide data about the cultural and physical history of the site. In this chapter, these data are described and interpreted and the results of the historical research are presented to provide a basis for assessing the significance of site $41 \mathrm{TT} 310$.

\section{Soils}

The sandy soils at site 41 TT310 are typical of those found in the uplands of Titus County. Thurmond (1981:23) provides the following description: "Sandy parent material, high rainfall variably distributed through the seasons, dense forest vegetation and the great age of landforms have combined to produce Ultisols with sandy ochric epipedons and underlying argillic horizons in most areas." Soils across the site are fairly uniform with a sandy loam $A$ horizon averaging $42 \mathrm{~cm}$ in thickness (range of 9 to $110 \mathrm{~cm}$ ) above a sandy clay B horizon (Fig. 6). The A horizon commonly grades from brown (10YR 5/3) and grayish brown (1OYR 5/2) to yellowish brown (1OYR 5/4) and brownish yellow (10YR 6/6) with depth; it shows abundant evidence of animal disturbances and contains numerous pieces of ferruginous sandstone distributed throughout (see Fig. 6). At the northeastern end of the site, this typical A horizon grades into a friable, compacted, pale brown (10YR 6/3) fine sandy loam which has numerous wavy iron oxide percolation lines and relatively little animal disturbance. Throughout the site, the sandy loam and fine sandy loam upper horizons are underlain by a 10-cm-thick transitional zone (compacted sandy loam/sandy clay) to the B horizon, which is commonly a yellowish red (5YR 5/8) to red (1OYR 4/6) sandy clay. As discussed later in this chapter, cultural materials occur throughout this sandy A horizon, a distribution which strongly suggests vertical movement of artifacts due to bioturbation.

\section{Features \\ Feature 1}

This cluster of ferruginous sandstone chunks (see Fig. 5b) was uncovered in the northwestern portion of Test Pit I between 22 and $28 \mathrm{~cm}$ below the current ground surface. The feature consists of 14 pieces of ferruginous sandstone that were plotted in situ and 8 other sizable fragments that were recovered from the screen before the feature was recognized. The stones do not form a continuous pavement but rather are scattered over a 54-by41-cm area. The feature probably extends north and west of Test Pit $I$, but no pit outline could be distinguished in the north and west walls of the pit or in two other cross sections cut into the feature. That the rock cluster was originally contained within a pit is suggested by the depth of the feature below the ground surface and the fact that the site appears to be on a nonaggrading landform. 
One of the sandstone fragments within the feature shows evidence of pecking and smoothing on one of its surfaces with two other surfaces exhibiting flake scars. The only other prehistoric artifact found within the test pit is an incised/engraved potsherd recovered from the level above the feature.

Several factors suggest that the cluster of stones represents the disrupted remnants of a hearth. First, ferruginous sandstone rocks of such size are not commonly found in the site soils. Second, the amount of charcoal within and around the cluster is significantly higher than that occurring elsewhere in the test pit matrix (although the amount recovered is insufficient for dating). Finally, the discrete clustering of these stones, the apparent evidence of burning shown by some of them, and the presence of the pecked, ground, and flaked artifact within the cluster indicate human activity.

\section{Feature 2}

This soil anomaly, with an average diameter of $22 \mathrm{~cm}$, was found in the northwestern corner of Test Pit $\mathrm{D}$. The feature was first distinguished by the dark color of its fill and was initially thought to be a post mold or pit. The north and west wall profiles show that the feature becomes visible at approximately $10 \mathrm{~cm}$ below the ground surface. With the removal of feature fill down to $75 \mathrm{~cm}$ below the ground surface, it became apparent that the feature is a tree root as the disturbance bifurcates, tapers, and undercuts eastward.

\section{Materials Recovered}

This section consists of three parts. The first describes all prehistoric artifacts recovered from the site. The second describes the historic Anglo-American artifacts. The third describes all nonartifactual remains. This section also provides provenience data for all specimens.

\section{Prehistoric Artifacts}

\section{CERAMICS}

The ceramic collection from 41 TT310 consists of 149 sherds which are described below and 59 very small or eroded fragments which are not analyzed here (these fragments are, however, included in Table 1). All of these sherds have the sandy clay paste typical of Caddoan pottery. No specimens of Williams Plain or the Early Ceramic period sandy paste wares are present in the collection. The following paragraphs describe these specimens in terms of surface treatment, decoration, temper, and vessel part. Although none of the sherds can be typed, similarities with existing types are noted where possible.

\section{$\underline{\text { Plain }}$}

This group is defined by the lack of any decoration and consists of 92 body sherds, 3 rim fragments, and 1 base sherd. Most of the specimens $(N=82)$ are tempered only with 


\section{ARCHEOLOGICAL TESTING AT 4ITT3IO \\ LAKE BOB SANDLIN STATE PARK \\ TEST PITS A \& B \\ EAST WALL PROFILE}

TEST PIT A

TEST PIT B

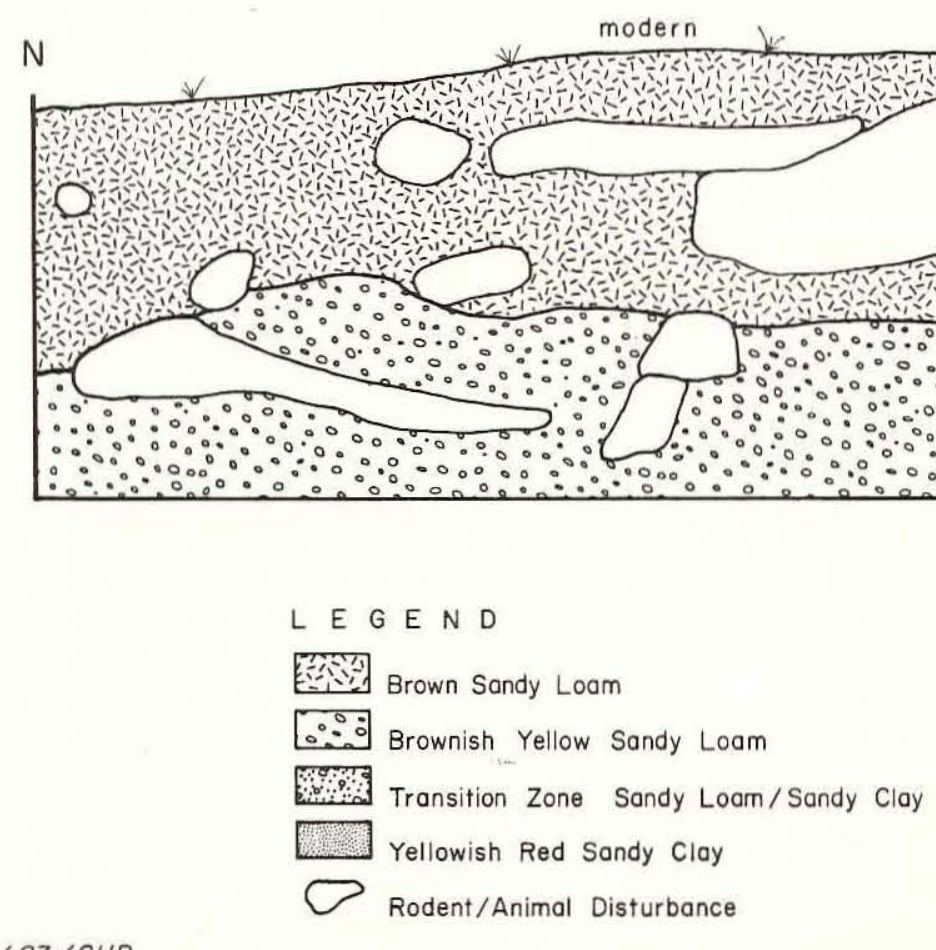

$P Q A I / 83 / S H P$

surface

TABLE 1

PROVENIENCE OF PREHISTORIC CERAMICS

\begin{tabular}{|c|c|c|c|c|c|c|c|c|c|c|c|c|c|}
\hline \multirow{2}{*}{ Provenience } & \multirow[b]{2}{*}{ Body } & \multirow{2}{*}{$\begin{array}{l}\text { PLAIN } \\
\text { Rim }\end{array}$} & \multirow[b]{2}{*}{ Base } & \multirow[t]{2}{*}{ BRUSHED } & \multicolumn{2}{|c|}{ PUNCTATED } & \multicolumn{3}{|c|}{ INCISED/ENGRAVED } & RED-SLIPPED & \multirow[t]{2}{*}{ PAINTED } & \multirow[t]{2}{*}{ SMALL* } & \multirow[b]{2}{*}{ Totals } \\
\hline & & & & & Body & Rim & $\begin{array}{l}\text { Horiz. } \\
\text { Lines }\end{array}$ & $\begin{array}{l}\text { Cross- } \\
\text { hatched }\end{array}$ & Misc. & & & & \\
\hline \multicolumn{14}{|l|}{ TEST PIT A } \\
\hline Level 1 & - & - & - & - & - & - & - & - & - & - & - & - & 0 \\
\hline Level 2 & 1 & - & - & - & - & - & - & - & - & - & - & - & 1 \\
\hline Level 3 & - & - & - & - & - & - & - & - & - & - & - & 1 & 1 \\
\hline Level 4 & 1 & - & - & - & - & - & - & - & - & - & - & - & 1 \\
\hline Level 5 & $\underline{1}$ & $=$ & $=$ & $=$ & $=$ & $=$ & $=$ & $=$ & $=$ & $=$ & $=$ & $\underline{1}$ & $\underline{2}$ \\
\hline Subtotals & 3 & 0 & 0 & 0 & 0 & 0 & 0 & 0 & 0 & 0 & 0 & 2 & 5 \\
\hline \multicolumn{14}{|l|}{ TEST PIT B } \\
\hline Level 1 & 1 & - & - & - & - & - & - & - & - & - & - & - & 1 \\
\hline Level 2 & 1 & - & - & - & - & - & - & - & - & - & - & 1 & 2 \\
\hline Level 3 & 1 & - & - & - & - & - & - & - & 1 & - & - & 1 & 3 \\
\hline Level 4 & - & - & - & - & - & - & - & - & - & - & - & 1 & 1 \\
\hline Level 5 & - & - & - & - & - & - & - & - & - & - & - & - & 0 \\
\hline Level 6 & - & - & - & - & - & - & - & - & - & - & - & - & 0 \\
\hline Level 7 & - & - & - & - & - & - & - & - & - & - & - & - & 0 \\
\hline Level 8 & $=$ & $=$ & $=$ & $=$ & $=$ & $=$ & $=$ & $=$ & $=$ & $=$ & $=$ & $=$ & $\underline{0}$ \\
\hline Subtotals & 3 & 0 & 0 & 0 & 0 & 0 & 0 & 0 & 1 & 0 & 0 & 3 & 7 \\
\hline \multicolumn{14}{|l|}{ TEST PIT C } \\
\hline Level 1 & 1 & - & - & - & - & - & - & - & - & - & - & 2 & 3 \\
\hline Level 2 & $\underline{1}$ & $=$ & $=$ & $=$ & $=$ & $=$ & $=$ & $=$ & $=$ & $=$ & $=$ & $=$ & $\underline{1}$ \\
\hline Subtotals & $\overline{2}$ & $\overline{0}$ & $\overline{0}$ & $\overline{0}$ & $\overline{0}$ & $\overline{0}$ & $\overline{0}$ & 0 & 0 & 0 & 0 & 2 & 4 \\
\hline
\end{tabular}

*Too small or too fragmented for analysis. 


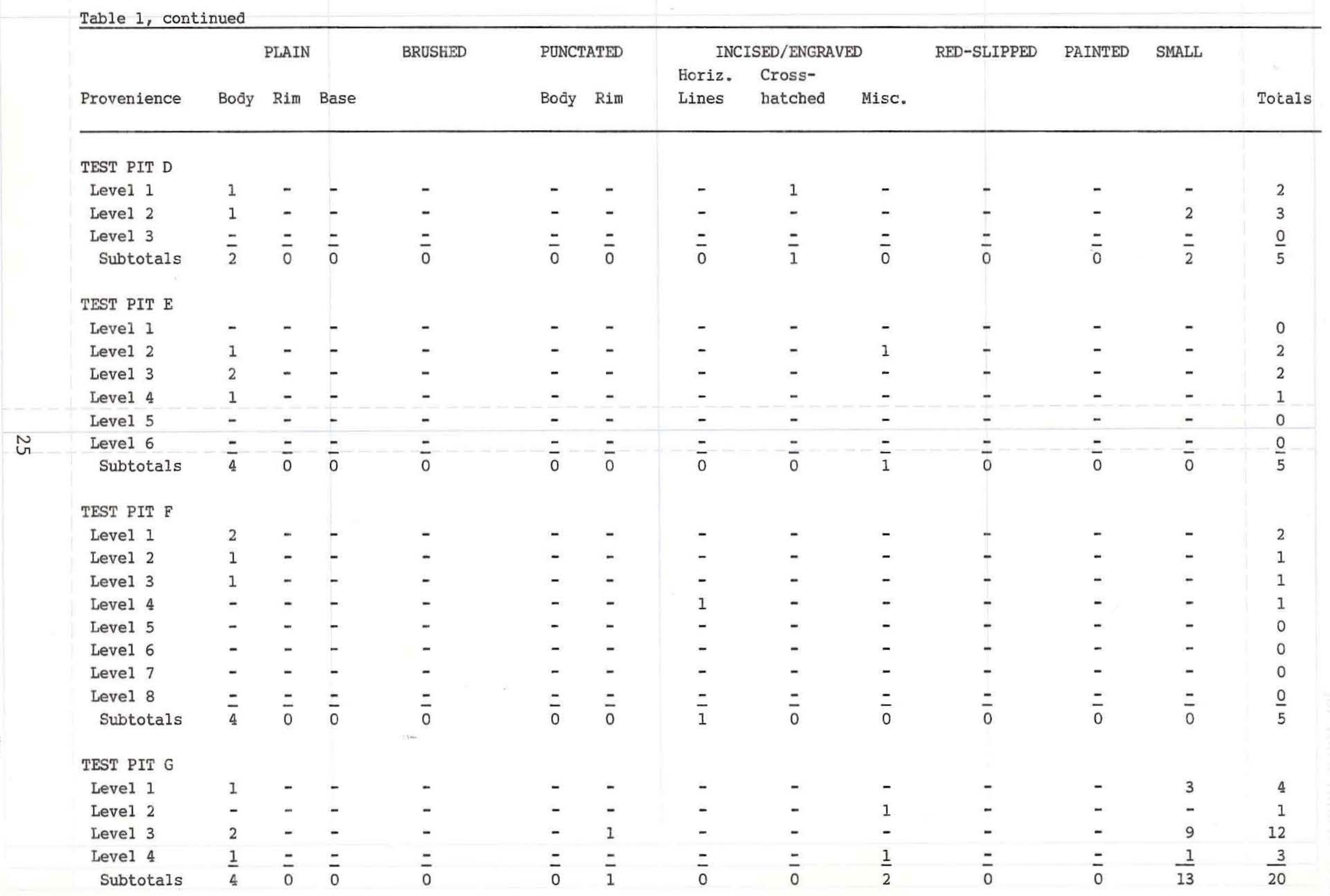


Table 1, continued

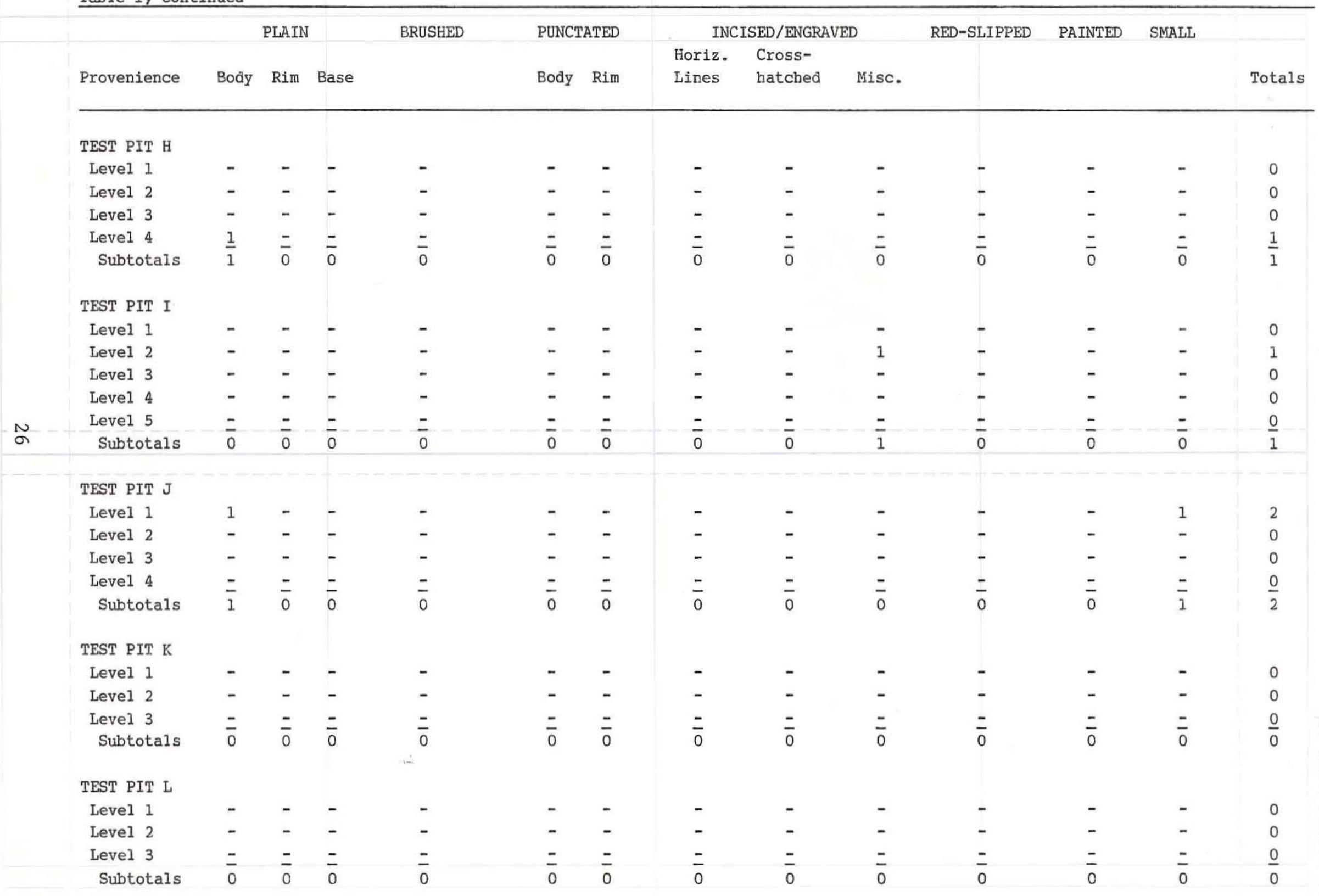


Table 1, continued

\begin{tabular}{|c|c|c|c|c|c|c|c|c|c|c|c|c|c|c|}
\hline & \multicolumn{3}{|c|}{ PLAIN } & & \multirow[t]{2}{*}{ BRUSHED } & \multicolumn{2}{|c|}{ PUNCTATED } & \multicolumn{3}{|c|}{ INCISED/ENGRAVED } & RED-SLIPPED & \multirow[t]{2}{*}{ PAINTED } & \multirow[t]{2}{*}{ SMALL } & \multirow[b]{2}{*}{ Totals } \\
\hline & Provenience & Body & Rim & Base & & Body & Rim & $\begin{array}{l}\text { Horiz. } \\
\text { Lines }\end{array}$ & $\begin{array}{l}\text { Cross- } \\
\text { hatched }\end{array}$ & Misc. & & & & \\
\hline & \multicolumn{14}{|l|}{ TEST PIT M } \\
\hline & Level 1 & - & - & - & - & - & - & - & - & - & - & - & - & 0 \\
\hline & Level 2 & - & - & - & - & - & - & - & - & - & - & - & - & 0 \\
\hline & Level 3 & - & - & - & - & - & - & - & - & - & - & - & 1 & 1 \\
\hline & Level 4 & - & - & - & - & - & - & - & - & - & - & - & - & 0 \\
\hline & Level 5 & $\Xi$ & $=$ & $\Xi$ & $=$ & $\Xi$ & $=$ & $=$ & $\Xi$ & $=$ & $=$ & $=$ & $=$ & $\underline{0}$ \\
\hline & Subtotals & 0 & 0 & 0 & 0 & 0 & 0 & 0 & 0 & 0 & 0 & 0 & 1 & 1 \\
\hline & \multicolumn{14}{|l|}{ TEST PIT N } \\
\hline & Level 1 & 3 & - & - & - & - & - & - & - & 1 & - & - & - & 4 \\
\hline & Level 2 & 5 & - & - & - & - & - & - & - & - & - & - & 2 & 7 \\
\hline & Level 3 & 3 & - & - & - & 1 & - & - & - & - & - & - & 2 & 6 \\
\hline & Level 4 & 1 & - & - & 3 & 2 & - & - & - & - & - & - & 5 & 11 \\
\hline & Level 5 & 1 & 1 & - & - & - & - & 1 & - & 2 & - & 1 & 1 & 7 \\
\hline \multirow{18}{*}{ 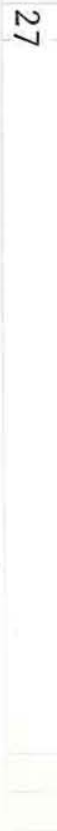 } & Level 6 & 4 & $=$ & $=$ & $=$ & $=$ & $=$ & $=$ & $\underline{1}$ & $\underline{1}$ & $=$ & $=$ & $=$ & 6 \\
\hline & Subtotals & 17 & 1 & 0 & 3 & 3 & 0 & 1 & 1 & 4 & 0 & 1 & 10 & 41 \\
\hline & \multicolumn{14}{|l|}{ TEST PIT 0} \\
\hline & Level 1 & - & - & - & - & - & - & - & - & - & - & - & 1 & 1 \\
\hline & Level 2 & - & - & - & - & - & - & - & - & - & - & - & - & 0 \\
\hline & Level 3 & - & - & - & - & - & - & - & - & - & - & - & - & 0 \\
\hline & Level 4 & $=$ & $=$ & $=$ & $=$ &  & $=$ & $=$ & $=$ & $=$ & $\Xi$ & $\Xi$ & $=$ & $\underline{0}$ \\
\hline & Subtotals & 0 & 0 & 0 & 0 & 0 & 0 & 0 & 0 & 0 & 0 & 0 & 1 & 1 \\
\hline & \multicolumn{14}{|l|}{ TEST PIT P } \\
\hline & Level 1 & 8 & - & - & 4 & - & - & - & - & 3 & - & - & 5 & 20 \\
\hline & Level 2 & 7 & - & - & 2 & 1 & - & - & - & 4 & - & - & 7 & 21 \\
\hline & Level 3 & 2 & 2 & 1 & 1 & - & 1 & - & - & 1 & - & - & 7 & 15 \\
\hline & Level 4 & 4 & - & - & - & - & - & - & - & - & - & - & 1 & 5 \\
\hline & Level 5 & 1 & - & - & 1 & - & - & - & - & 1 & - & - & 1 & 4 \\
\hline & Level 6 & 1 & - & - & - & - & - & - & - & 2 & - & - & 1 & 4 \\
\hline & Level 7 & - & - & - & - & - & - & - & - & - & - & - & - & 0 \\
\hline & Level 8 & $=$ & $=$ & $=$ & $=$ & $=$ & $=$ & $\Xi$ & $=$ & $=$ & $=$ & $=$ & $=$ & 0 \\
\hline & Subtotals & 23 & 2 & 1 & 8 & 1 & 1 & 0 & 0 & 11 & 0 & 0 & 22 & 69 \\
\hline
\end{tabular}


Table 1, continued

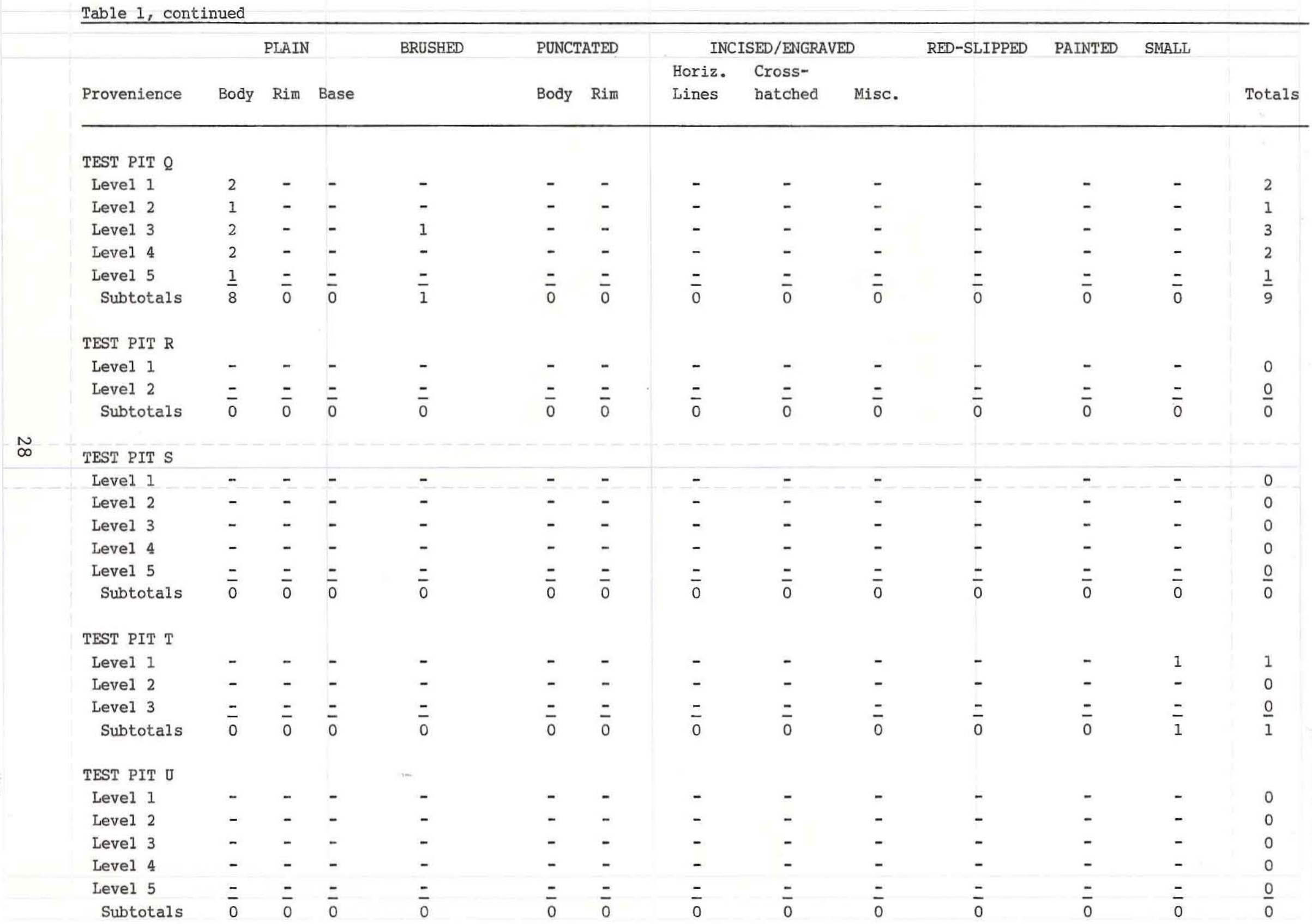


Table 1, continued

\begin{tabular}{|c|c|c|c|c|c|c|c|c|c|c|c|c|c|}
\hline \multirow[b]{2}{*}{ Provenience } & \multirow[b]{2}{*}{ Body } & \multirow{2}{*}{$\begin{array}{l}\text { PLAIN } \\
\text { Rim }\end{array}$} & \multirow[b]{2}{*}{ Base } & \multirow[t]{2}{*}{ BRUSHED } & \multicolumn{2}{|c|}{ PUNCTATED } & \multicolumn{3}{|c|}{ INCISED/ENGRAVED } & RED-SLIPPED & \multirow[t]{2}{*}{ PAINTED } & \multirow[t]{2}{*}{ SMALL } & \multirow[b]{2}{*}{ Totals } \\
\hline & & & & & Body & Rim & $\begin{array}{l}\text { Horiz. } \\
\text { Lines }\end{array}$ & $\begin{array}{l}\text { Cross- } \\
\text { hatched }\end{array}$ & Misc. & & & & \\
\hline \multicolumn{14}{|l|}{ MOTOR GRADER } \\
\hline CUT $5 \mathrm{~A}$ & 10 & - & - & 1 & - & 1 & - & - & - & 2 & - & - & 14 \\
\hline CUT 5B & 7 & - & - & - & 1 & - & 1 & 1 & 1 & - & - & - & 11 \\
\hline CUT 6 & 1 & - & - & - & - & - & - & - & 2 & - & - & - & 3 \\
\hline MISCELLANEOUS & 2 & - & - & - & - & - & - & - & - & - & - & 1 & 3 \\
\hline TOTALS & 92 & 3 & 1 & 13 & 5 & 3 & 3 & 3 & 23 & 2 & 1 & 59 & 208 \\
\hline & & & & & & & & & & & & & \\
\hline$\%$ of Total & 44.2 & 1.4 & 0.5 & 6.2 & 2.4 & 1.4 & 1.4 & 1.4 & 11.1 & 1.0 & 0.5 & 28.4 & 99.9 \\
\hline $\begin{array}{l}\% \text { of Total } \\
\text { Minus Too } \\
\text { Small or }\end{array}$ & & & & & & & & & & & & & \\
\hline Fragmented & 61.7 & 2.0 & 0.7 & 8.7 & 3.4 & 2.0 & 2.0 & 2.0 & 15.4 & 1.3 & 0.7 & & 99.9 \\
\hline
\end{tabular}


grog; 14 of the body sherds (15\% of the plain specimens) are tempered with both grog and bone. The thickness and curvature of most of the sherds suggest that large, simple jars are represented. Two of the rim fragments are from everted-rim jars, both with orifice diameters of $12 \mathrm{~cm}$; the third rim sherd is too small to provide information on vessel shape or size. All of these rims have simple rounded lips. The base fragment is planoconvex in cross section and represents a vessel base approximately $7 \mathrm{~cm}$ in diameter.

$\underline{\text { Brushed }}$

Thirteen body sherds are decorated with brushing. All are tempered with grog. As with the plain sherds, the brushed specimens appear to represent large, simple jars. Although these sherds cannot be typed with any confidence, it should be noted that brushing does occur on several types -- such as Pease Brushed-Incised, Maydelle Incised, and Bullard Brushed (Suhm and Jelks 1962:21-22, 103-104, 119-120) -- which are found in archeological sites in the Cypress Creek drainage.

Punctated

Five body sherds and three rim fragments are decorated with punctations. Two of the body sherds have fields of fingernail punctations such as those found on the types Dunkin Incised, Kiam Incised, and Weches Fingernail-Impxessed (Suhm and Jelks 1962:37-38, 89-90, 153-154). The remaining three body sherds appear to represent the neck portion of vessels and have small punctations made with a pointed or crescent-shaped tool. One of the three (Fig. 7a) has two horizontal rows of punctations; one has a single row of punctations (orientation uncertain); and the third has a field of punctations bordered by a straight incised line (Fig. $7 \mathrm{~b})$. None of these can be typed, but the last appears to contain a motif resembling one of those illustrated for the type Maydelle Incised (Suhm and Jelks $1962: 103-104$ ).

All three of the rim sherds appear to contain fields of punctations which have been made with pointed or blunt tools. None of these rim fragments show incised lines bordering the punctations. One rim has a rolled and poorly finished lip; one has a simple squared lip; and one has a simple rounded lip. None of these rim fragments can be typed.

All of these punctated sherds are tempered only with grog. All appear to represent simple jars. The single sizable rim fragment is from an everted rim jar with an orifice diameter of $17 \mathrm{~cm}$.

\section{Incised and Engraved}

This group includes 26 body sherds and 3 rim sherds which are decorated with incised or engraved lines. All three rim fragments have multiple horizontal, incised 1 ines (1-2 mm apart) beneath the lip. On all three, the lines have been carelessly executed (Fig. 7c), and on one sherd the lines may have been created by brushing. Two of these rim fragments are tempered with grog; the third has grog and bone temper. The two largest rims appear to represent vertical-walled jars with orifice diameters of 9 and $17 \mathrm{~cm}$. Two of the sherds have simple rounded lips; the third has a slightly rolled lip. While a number of Caddoan types -- such as Davis Incised, Dunkin Incised, and Kiam Incised (Suhm and Jelks 1962:3538, 89-90) -- have this sort of rim decoration, none of the specimens in this collection can be typed. 
The three most distinctive incised and engraved body sherds display broad crosshatching reminiscent of that seen on the rim and neck of Maydelle Incised vessels (Suhm and Jelks 1962:103-104). All three are tempered with grog and are too small to yield information on vessel form.

The remaining 23 incised and engraved body sherds bave multiple parallel straight lines $(N=8)$, single straight lines $(N=13)$, or single curved lines $(N=2)$. Fifteen are tempered only with grog; eight $(35 \%)$ are tempered with grog and bone. None of the sherds in this nondistinctive group can be typed.

\section{$\underline{\text { Red Slipped }}$}

Two small body sherds show a red slip on their exterior faces. Other than the slip, these specimens are undecorated. Munsell colors on the slips are 5YR 4/6 (yellowish red) and 2.5YR 5/6 (red). One of these sherds is tempered only with grog; the other has grog and bone temper.

\section{Painted (?)}

One grog-tempered rim sherd appears to have been decorated with a painted black stripe on the interior of the lip. This stripe is $1.5 \mathrm{~mm}$ wide and extends for a distance of 4.5 $\mathrm{mm}$ along the rim. Slight discoloration of the remainder of the length of the rim suggests that the stripe may have at one time extended along the entire rim. This rim fragment appears to be from a bowl with a sharply inverted rim (orifice diameter $=14 \mathrm{~cm}$ ).

\section{CHIPPED STONE}

The chipped stone category consists of 7 tools and tool fragments and 151 pieces of debitage. In this section, individual tool descriptions are presented first followed by a discussion of the debitage.

Tools

Dart Points

Two dart point fragments made of quartzite are the only diagnostic stone tools found during the investigations at 41 TT310 (Table 2). One of these specimens is a serrated and alternately beveled blade fragment which was found in Level 7 of Test Pit F (Fig. 7d). The distal end and one of the shoulders of the blade are missing with a spurlike projection on the intact shoulder apparently being caused by resharpening of the blade. Due to the fragmentary nature of the specimen, the only measurement taken is maximum thickness (7.5 mm). Although the stem is lacking, blade attributes suggest that it is a middle Archaic Neches River dart point (Jelks 1965:140-141).

The second specimen is a very small dart point that was recovered from Level 4 of Test Pit $\mathrm{P}$ (Fig. 7e). Although the base is missing, the remaining portion of the stem narrows toward the bottom. The short blade, which is $15 \mathrm{~mm}$ in length, appears to bave been 
Figure 7. Artifact Illustrations.

a. Body sherd with two horizontal rows of punctations.

b. Body sherds with punctations and an incised line.

c. Rim sherd with multiple incised lines.

d. Neches River dart point fragment.

e. Gary dart point fragment.

f. Polished celt fragment.

All artifacts are illustrated actual size. 
Figure 7
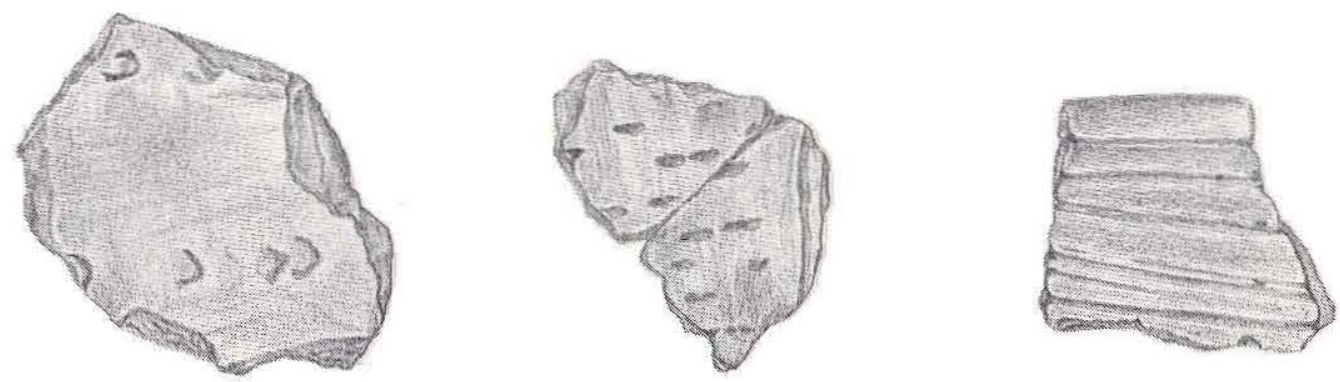

b

c
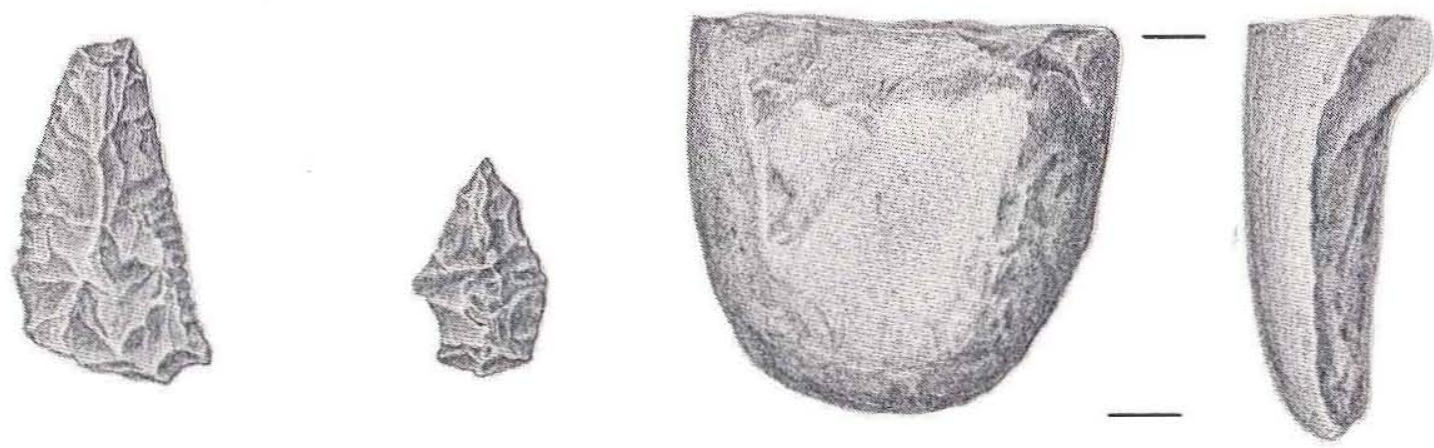

$d$

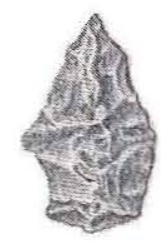

$e$

f

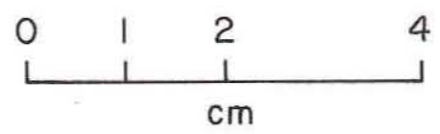

$B_{1 H}$ 
resharpened. The blade has shoulders but lacks barbs. A maximum blade width of $13.5 \mathrm{~mm}$ occurs at the shoulders, and the maximum thickness is $6 \mathrm{~mm}$. Typologically, this appears to be a Gary dart point. It is similar to the small Garys found at 41TT108 (Young 1981:30-32) and to the Contracting Stem, Form I, Variety 5 group at 41TT110 (Flaigg 1982:107). Dart points such as this one are commonly found in late Archaic, Early Ceramic, and Caddoan contexts in the project region (Johnson 1962:268-280; Young 1981:30-32)

Biface Fragments

Four biface fragments were identified during the analysis. One of these appears to be well thinned with portions of two contiguous sides present. It is made of gray Edwards Plateau chert and was found in Level 3 of Test Pit J. Although the specimen is badly heatspalled, the fine retouch on the edges suggests that it may have come from a finished tool. Due to the fragmentary nature of the artifact, no measurements are given.

Another biface fragment is a very small distal end of a reddish pink quartzite tool that was found in Level 2 of Test Pit B. An impact scar on the tip suggests that it is a finished tool that was broken during usage.

The third biface fragment is a tabular piece of silicified wood that was found in Level 5 of Test Pit E. The maximum width is $29 \mathrm{~mm}$ while the maximum thickness is $7.5 \mathrm{~mm}$. No maximum length is given because the distal end is missing. One lateral edge has been bifacially flaked to produce a thinned edge which could have been utilized. An impurity is present, however, on the opposing blade edge. Apparently unsuccessful attempts to remove this impurity resulted in a blocky, jagged edge. This suggests that the artifact could be a rejected preform.

The final biface fragment is of quartzite and has parts of two contiguous sides meeting at a rounded angle. The shape of the fragment suggests that the complete specimen was lenticular in cross section. The secondary retouch on the margins of the tool suggests that it is a finished tool broken during usage. It was recovered from Level 3 of Test Pit T.

Retouched Flake

Only one retouched flake was identified during the analysis. This complete specimen is of chert and measures 22 by 11 by $3 \mathrm{~mm}$. A small concavity on one edge has been unifacially modified as has a convex area on the opposite edge. It was found in Level 1 of Test Pit L.

\section{Debitage}

A total of 151 pieces of lithic debitage were recovered during investigations at 41TT310. Provenience of these specimens is given in Table 3. These artifacts have been classified by material type and placed in either flake, chip, or angular fragment categories. A further subdivision into cortical and interior groups is based on (1) the simple presence or absence of cortex on the dorsal surface in the case of flakes and chips, or (2) the presence or absence of cortex on most of any one surface in the case of angular fragments. Additionally, the whole flakes and flake fragments retaining platforms have been grouped according to platform type -- single faceted, multiple faceted, cortex, and miscellaneous (crushed, ground, and collapsed). 
TABLE 2

PROVENIENCE OF LITHIC TOOLS

\begin{tabular}{|c|c|c|c|c|c|c|c|}
\hline $\begin{array}{l}\text { Prove- } \\
\text { nience }\end{array}$ & $\begin{array}{l}\text { Dart } \\
\text { Points }\end{array}$ & $\begin{array}{l}\text { Biface } \\
\text { Fragments }\end{array}$ & $\begin{array}{l}\text { Retouched } \\
\text { Flake }\end{array}$ & $\begin{array}{l}\text { Ground and } \\
\text { Pecked Stones }\end{array}$ & $\begin{array}{l}\text { Polished } \\
\text { Celt }\end{array}$ & $\begin{array}{l}\text { Abraded } \\
\text { Stone }\end{array}$ & $\begin{array}{l}\text { Scratched } \\
\text { Stone }\end{array}$ \\
\hline \multicolumn{8}{|l|}{ TEST PIT B } \\
\hline & 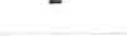 & & 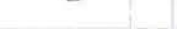 & - & & - & - \\
\hline \multicolumn{8}{|l|}{ TEST PIT E } \\
\hline Level 5 & - & 1 & - & - & - & - & - \\
\hline \multicolumn{8}{|l|}{ TEST PIT $\mathrm{F}$} \\
\hline Level 7 & 1 & - & - & - & - & - & - \\
\hline \multicolumn{8}{|l|}{ TEST PIT I } \\
\hline (Feature 1) & ) - & - & - & 1 & - & - & - \\
\hline \multicolumn{8}{|l|}{ TEST PIT J } \\
\hline Level 3 & - & 1 & - & - & - & - & - \\
\hline \multicolumn{8}{|l|}{ TEST PIT L } \\
\hline Level 1 & - & - & 1 & - & - & - & - \\
\hline \multicolumn{8}{|l|}{ TEST PIT N } \\
\hline Leve1 6 & - & - & - & - & - & 1 & - \\
\hline \multicolumn{8}{|l|}{ TEST PIT P } \\
\hline Level 3 & - & - & - & - & 1 & - & - \\
\hline Level 4 & 1 & - & - & - & - & - & - \\
\hline \multicolumn{8}{|l|}{ TEST PIT $R$} \\
\hline Level 1 & - & - & - & 1 & - & -1 & - \\
\hline \multicolumn{8}{|l|}{ TEST PIT T } \\
\hline Level 3 & - & 1 & - & - & - & - & - \\
\hline \multicolumn{8}{|l|}{ MOTOR GRADER } \\
\hline CUT $5 B$ & $=$ & $=$ & $=$ & $=$ & $=$ & $=$ & $\underline{1}$ \\
\hline TOTALS & 2 & 4 & 1 & 2 & 1 & 1 & 1 \\
\hline
\end{tabular}


TABLE 3

PROVENIENCE OF DEBITAGE

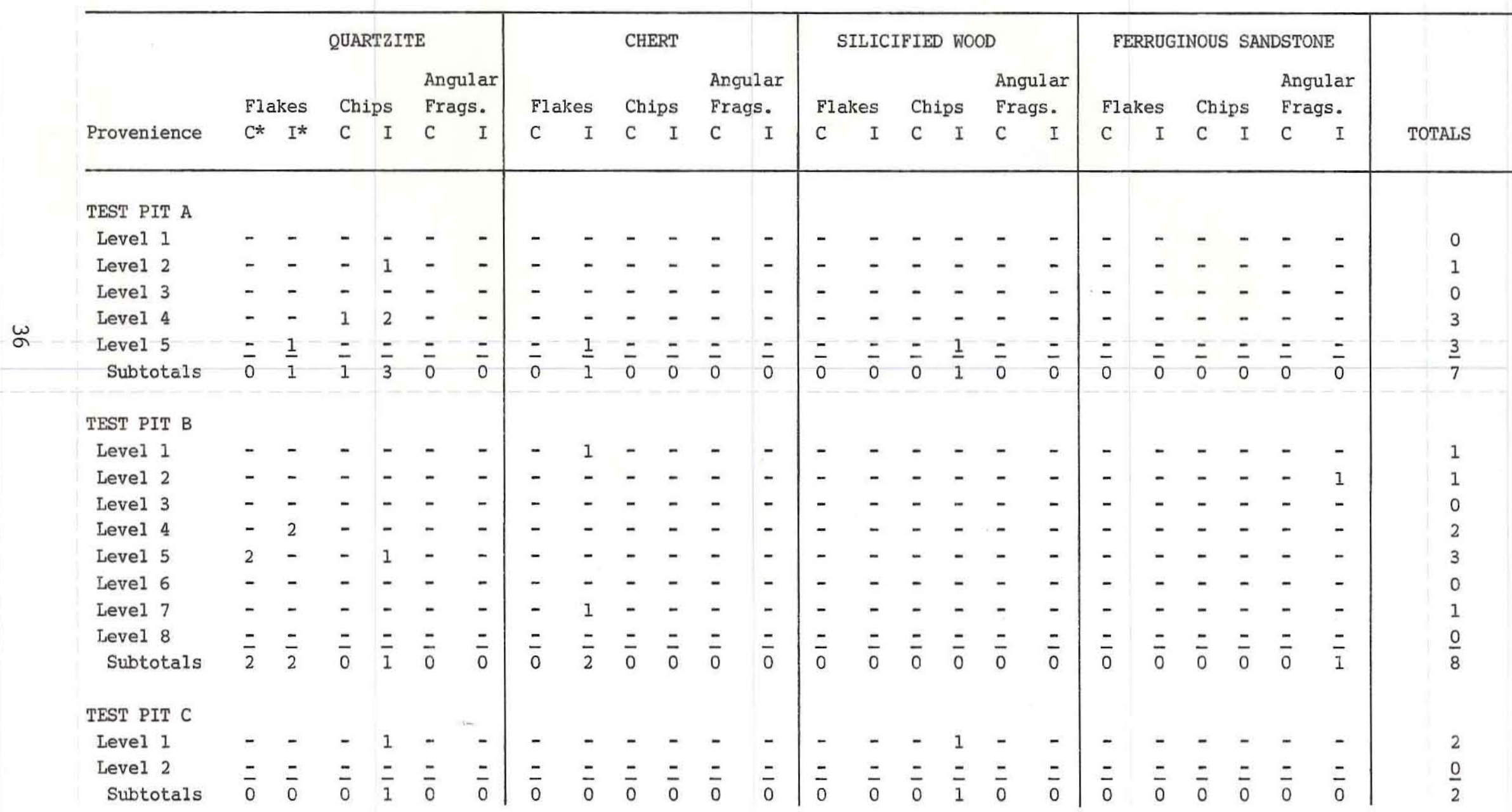

* $\mathrm{C}=$ cortical; $I$ = interior. 
Table 3 , continued

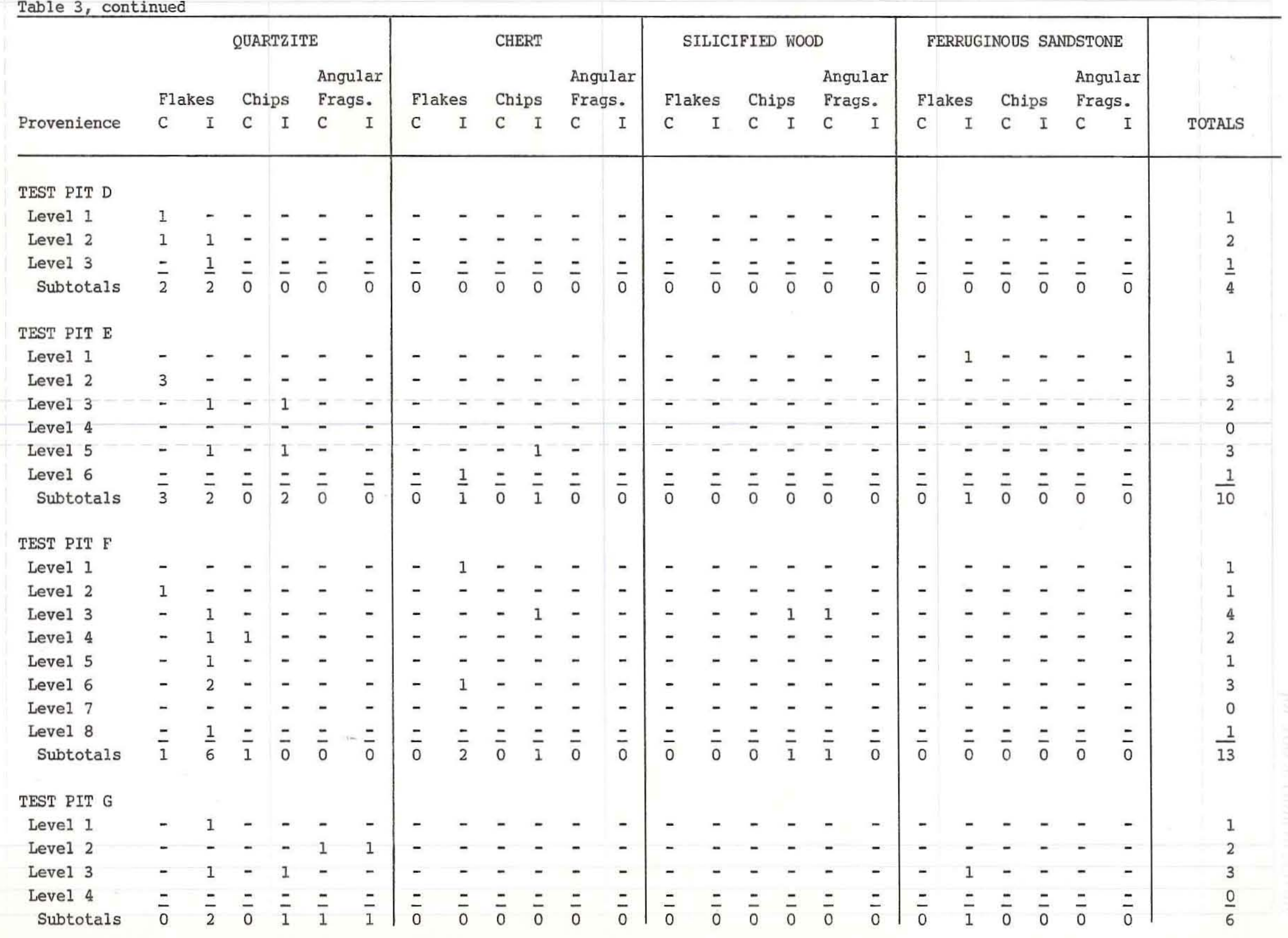


Table 3 , continued

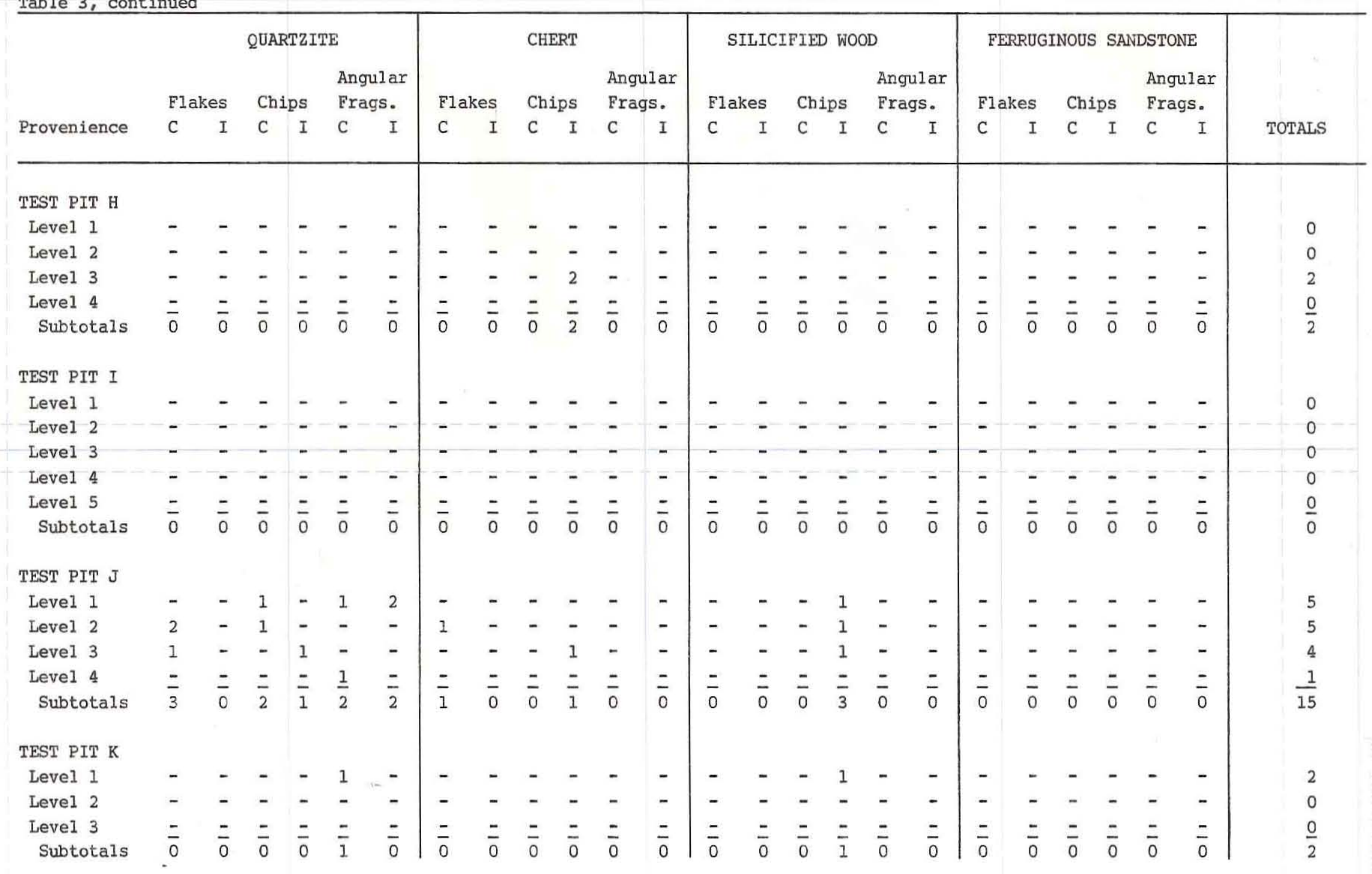


Table 3, continued

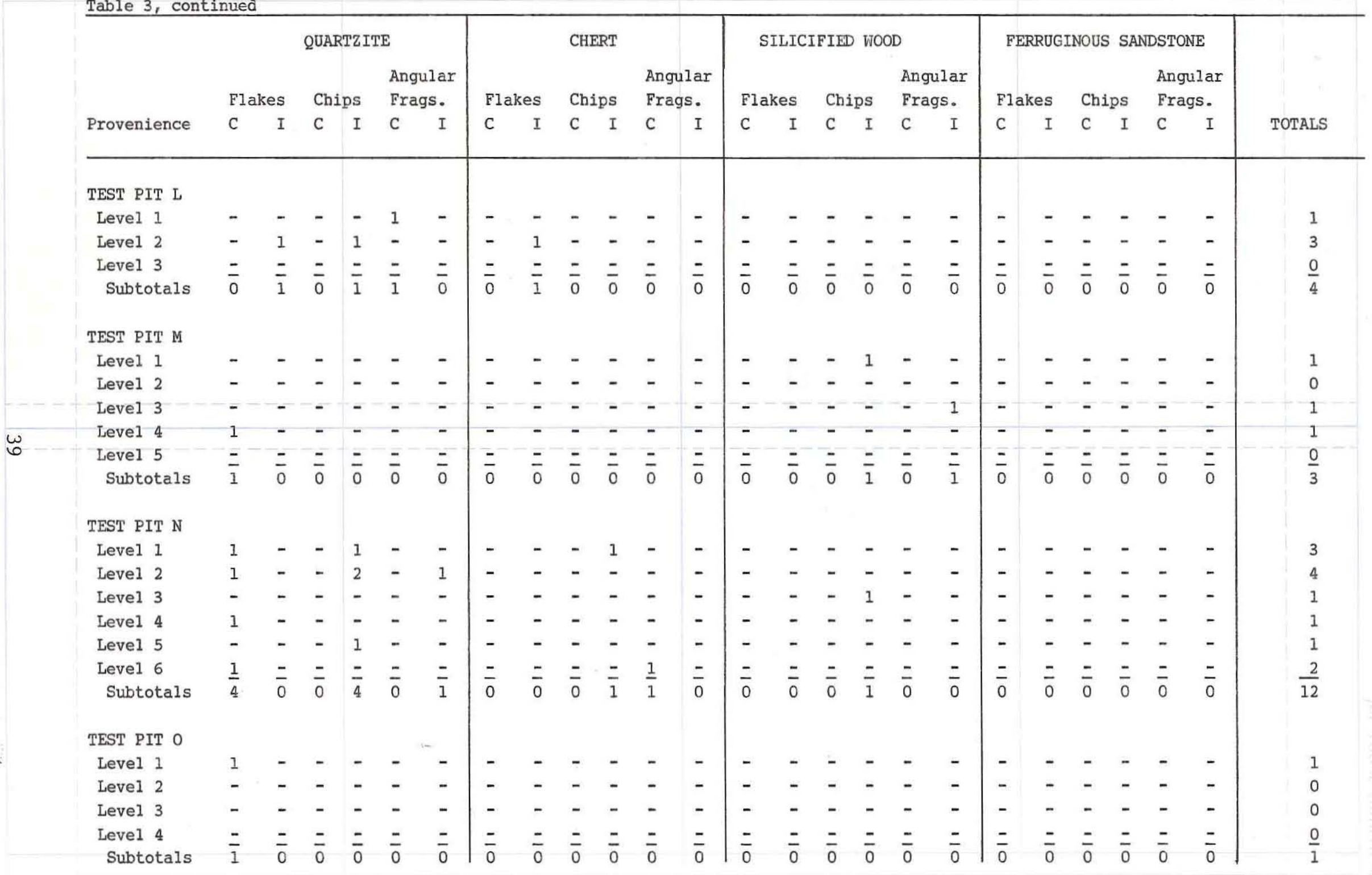


Table 3 , continued

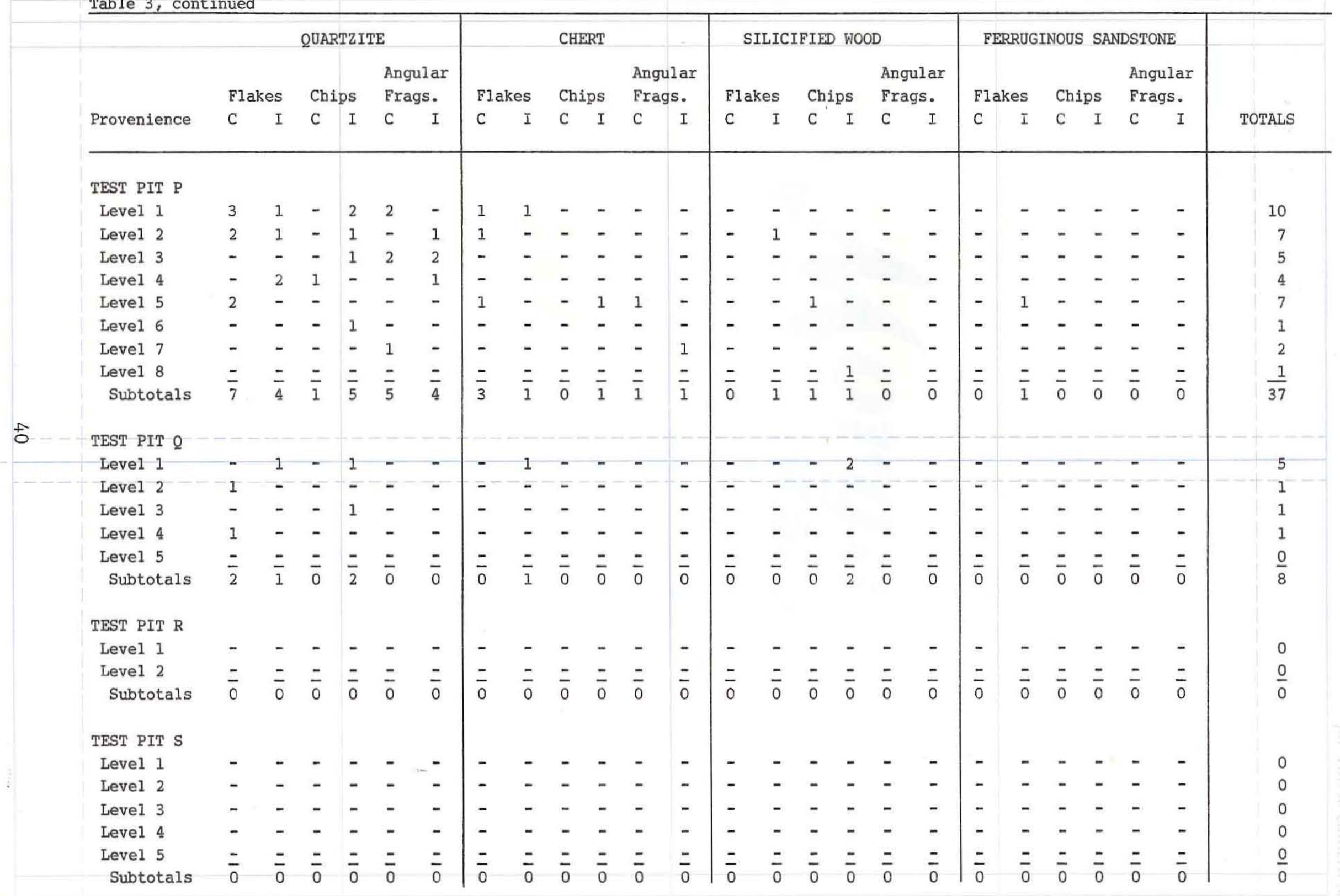


Table 3, continued




As shown in Table 3, four materials -- quartzite, silicified wood, ferruginous sandstone, and chert -- are present in the debitage collection. Quartzite clearly predominates as it accounts for $66 \%$ of the debitage. Chert and silicified wood comprise $16 \%$ and $15 \%$ of the collection. Ferruginous sandstone is least frequent, constituting only $3 \%$.

The debitage from 41 TT310 demonstrates that locally available materials were the most frequently utilized. In fact, the only readily apparent nonlocal material is represented by a few specimens of Edwards Plateau chert. Much, if not all, of the other chert could have come from gravel deposits in the immediate vicinity.

These percentages of material types are similar to those shown by Flaigg $(1982: 64)$ for the much larger collection from site 41TT110. Elsewhere, Young's (1981) large percentage of chert at 41TT108 is probably due to his designation of fine-grained siliceous materials from the Ogallala Formation as chert rather than quartzite.

Although the sample is small, there are suggestions that the entire lithic reduction sequence is represented. While cores are absent, 38\% of the total debitage has a cortex surface and $25 \%$ of the flakes have some cortex. The percentage of flakes with cortex platforms at 41TT310 is approximately four times greater than that at 41TT110. As at 41TT110, over one-half of the angular fragments have cortex suggesting that they are products of core reduction. Overall, there is considerable evidence for initial reduction.

The evidence for the final stages of bifacial lithic reduction at 41 TT310 is problematical. Although multiple faceted platform flakes are present, they comprise only $16 \%$ of the collection, a percentage which is much lower than the overall $46.7 \%$ average at 41 TT110. Flaigg (1982:95) notes that higher percentages of multiple faceted platforms $(52.9 \%)$ occur in three Archaic period units at 41TT110 while the one Late Prehistoric period unit has a lower percentage of $39.1 \%$. The percentage of multiple faceted platforms at 41 TT310 suggests that the finishing of preforms was not a major activity at 41TT310.

Notably lacking in the lithic collection from 41 Tr310 are edge-modified flakes. The single specimen found represents less than $1 \%$ of the collection whereas at 41 TT110 the overall average is 10\% (Flaigg 1982:74). Again, however, it should be reiterated that the size of the sample from 41 TT310 is small.

MISCELLANEOUS STONE ARTIFACTS

Ground and Pecked Stones

One specimen from Level 1 of Test Pit $\mathrm{R}$ has pecking and light smoothing on both faces. The maximum length of the ferruginous sandstone fragment is $113 \mathrm{~mm}$; maximum width is $69 \mathrm{~mm}$; maximum thickness is $48 \mathrm{~mm}$. The size and shape of the artifact suggest that it is an exterior edge of a grinding slab fragment.

Another ferruginous sandstone fragment with a partially pecked and smoothed surface was found within Feature 1, the probable disrupted hearth in Test Pit I. Two surfaces of the specimen also show flake scars. The artifact fragment measures 88 by 77 by $35 \mathrm{~mm}$. It could be a broken grinding stone or a handstone fragment. 


\section{Polished Celt}

The proximal end of a polished stone celt was recovered from Level 3 of Test Pit P (Fig. 7f). Made of ferruginous sandstone, the tool has been symmetrically shaped by chipping, pecking, and polishing. It is lenticular in cross section, and the majority of the surface has been smoothed. In addition to having been broken across its narrow axis (possibly near the haft), a large flake bas been detached from the proximal end. The surface exposed by the removal of this flake has also been pecked. The maximum width and thickness of the celt fragment are 43 and $21 \mathrm{~mm}$.

\section{Abraded Stone}

A natural groove in a ferruginous sandstone fragment found in Level 6 of Test Pit $N$ may have been utilized as an abrader. The maximum dimensions of the specimen are 88 by 40 by $22 \mathrm{~mm}$. The grooved area is located on one of the long axis surfaces and is flanked by narrow ridges. The grooved area narrows from 26 to $10 \mathrm{~mm}$. A majority of the mid portion of the grooved area is smoothed suggesting that the stone may have functioned as an abrading stone.

\section{Scratched Stone}

A hematite cobble measuring 57 by 54 by $27 \mathrm{~mm}$ with numerous scratch marks on its surfaces was recovered from the backdirt of $M G 5 B$. The nature of the scratching is highly variable. Several relatively long, wide marks could represent recent plow marks or aboriginal attempts to detach hematite fragments for use as pigment. Most, however, are short, narrow etchings which occur haphazardly or in parallel rows on the edges of the stone.

\section{CERAMICS}

$\underline{\text { Edged Ware }}$

Historic Artifacts

Six sherds of edged ware were recovered from 41 TT310 (Table 4). Edge-decorated wares were first manufactured in England by Josiah Wedgewood about 1765 (Noel-Hume 1970:242). They consisted of a molded rim pattern painted in blue underglaze. On some, the painting was green, and a few were painted in a pinkish red. The manufacture of this design by English potters lasted until the mid nineteenth century. Edge-decorated wares such as feather and shell were made on pearlware from 1810 to 1830 when pearlware was no longer used in manufacturing. The term pearlware suffers from the lack of an exclusive definition. Noel-Hume (1978:47) notes that, when cobalt blue is added to a lead glaze, it obscures the natural yellowish color of the lead glaze. A pile-up of the glaze around the ring foot, for example, evidences this blue color. However, in later glazes which are not pearlware, specks of blue may be seen in the glaze. Price (1979) suggests that pearlware can be distinguished from whitewares by a blue tinge of the glaze when compared to whiteware glazes. The edge-decorated sherd from Test Pit $J$ seems to have a blue tinge. It also has a scalloped rim (Fig. 8a), which would tend to support its pearlware identification. 
TABLE 4

PROVENIENCE OF HISTORIC ARTIFACTS

\begin{tabular}{|c|c|c|c|c|c|c|c|c|c|c|c|c|c|}
\hline & \multicolumn{5}{|c|}{ Test Pits } & \multicolumn{8}{|c|}{ Motor Grader Cuts } \\
\hline & A & B & $\mathrm{E}$ & I & $\mathrm{J}$ & $\mathrm{L}$ & $\mathrm{S}$ & $5 A$ & $5 B$ & $5 \mathrm{C}$ & 6 & 8 & Totals \\
\hline \multicolumn{14}{|l|}{ CERAMICS } \\
\hline \multicolumn{14}{|l|}{ Edged ware } \\
\hline Shell whiteware & - & - & - & - & - & - & - & 4 & 1 & - & - & - & 5 \\
\hline Shell pearlware & - & - & - & - & 1 & - & - & - & - & - & - & - & 1 \\
\hline Plain whiteware & 1 & 2 & - & - & 2 & 1 & - & 17 & 7 & - & - & 2 & 32 \\
\hline Plain pearlware & - & - & - & - & - & - & - & 1 & - & - & - & - & 1 \\
\hline Transfer-printed whiteware & - & - & - & - & 1 & - & - & - & - & - & - & - & 1 \\
\hline Hand-painted whiteware & - & - & - & - & - & - & - & - & 1 & - & - & - & 1 \\
\hline Hard paste earthenware & 1 & - & - & - & - & - & - & 4 & - & - & - & - & 5 \\
\hline Stoneware & - & - & - & - & - & - & - & 1 & 1 & 1 & - & - & 3 \\
\hline Porcelain wheel fragment & $=$ & $=$ & $=$ & $=$ & $=$ & $=$ & $=$ & $\underline{1}$ & $=$ & $=$ & $=$ & $=$ & 1 \\
\hline Subtotals & 2 & 2 & 0 & 0 & 4 & J. & 0 & 28 & 10 & 1 & 0 & 2 & 50 \\
\hline \multicolumn{14}{|l|}{ METAL } \\
\hline Cut nails & 4 & 1 & - & - & 1 & 1 & - & 2 & - & - & - & - & 9 \\
\hline Wire nails & 1 & - & - & 1 & - & - & 1 & - & - & - & - & - & 3 \\
\hline Other & $=$ & $\underline{2}$ & $=$ & $=$ & $=$ & $=$ & $=$ & $\underline{3}$ & $=$ & $=$ & $=$ & $=$ & $\underline{5}$ \\
\hline Subtotals & 5 & 3 & 0 & 1 & 1 & 1 & 1 & 5 & 0 & 0 & 0 & 0 & 17 \\
\hline \multicolumn{14}{|l|}{ GLASS } \\
\hline Clear & - & 1 & - & - & 1 & - & - & 2 & - & - & - & 1 & 5 \\
\hline Amethyst & - & 1 & - & - & - & - & - & - & 2 & - & - & - & 3 \\
\hline Brown & 1 & - & 1 & - & - & - & - & 6 & 1 & - & - & $-i$ & 9 \\
\hline Olive green & 2 & 1 & - & - & - & - & - & 5 & - & - & 1 & - & 9 \\
\hline Aqua & - & 1 & - & - & - & - & - & 1 & 4 & - & - & - & 6 \\
\hline Amber & $\Xi$ & $\underline{1}$ & $=$ & $\Xi$ & $=$ & $=$ & $=$ & $=$ & $=$ & $=$ & $=$ & $=$ & 1 \\
\hline Subtotals & 3 & 5 & 1 & 0 & 1 & 0 & 0 & 14 & 7 & 0 & 1 & 1 & 33 \\
\hline BUTTON & - & - & - & - & - & - & - & - & 1 & - & - & - & 1 \\
\hline BRICK FRAGMENTS & - & - & - & - & - & - & 15 & - & - & - & - & - & 15 \\
\hline TOTALS & 10 & 10 & 1 & 1 & 6 & 2 & 16 & 47 & 19 & 1 & 1 & 3 & 117 \\
\hline
\end{tabular}




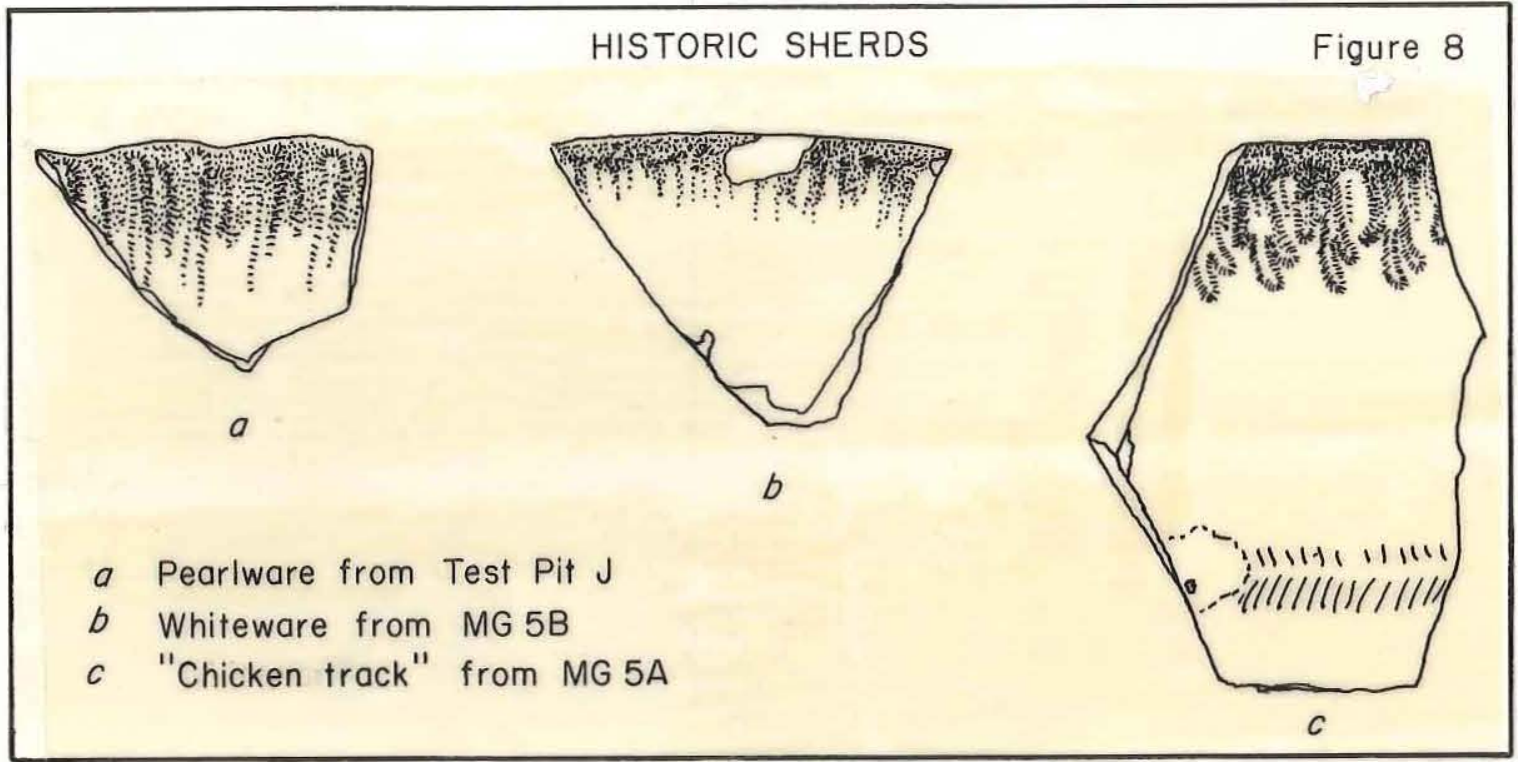

The five edge-decorated sherds from MG 5A and MG 5B are from two vessels, probably plates. Since no ring foot is present on these sherds to distinguish whether or not they are pearlware, the sherds were compared in color to a whiteware glazed sherd and were found to have no blue tinge; therefore, they cannot be classed as pearlware. All the sherds are from straight-rim vessels except the sherd from Test Pit J. The molded design on one of the sherds from MG $5 \mathrm{~A}$ (Fig. $8 \mathrm{C}$ ) is similar in design to the "chicken-foot" design found only on nineteenth-century pearlware and white earthenware (Sussman 1977:107). The other sherds have lines that curve downward from the rim. All the edged ware sherds date before 1860.

\section{Plain Whiteware and Pearlware}

Thirty-three plainware sherds were recovered. All but one are nondistinctive whiteware specimens. The exception is a possible pearlware sherd from MG 5A.

\section{Transfer-Printed Whiteware}

This small sherd is a base fragment from a probable bowl. The ring foot is $6 \mathrm{~cm}$ in diameter and about $1 \mathrm{~cm}$ high. Transfer color is a brown-lavender with a scene depicting mountains and part of a mosque. This color came into production after 1850 . Norman-Wilcox (1978:168) describes this color as "an unpleasant faded-brown purple shade known for some obscure reason as 'mulberry'."

\section{Hand-Painted Whiteware}

This small sherd has a black painted line on the rim and a reddish pink design element, both painted underglaze. This technique was developed in England about 1750 with finer lined painting being produced after 1830 (Ramsey 1939:153). Since this sherd does not have a pearlware glaze and has a fine line execution, its manufacture date would be after 1830 . 


\section{Hard-Paste Earthenware}

This category refers to "ironstone," "granite ware," "semi-porcelain," "stone china," etcetera. These sherds have no manufacturing marks, but are of the quality of these wares. This type of paste -- hard, dense, and opaque, sometimes with a slight greyish color -- was developed about 1850 by English potters and between 1860-1900 by American potters (Ramsey 1939:153).

\section{Stoneware}

The sherd from MG $5 \mathrm{~A}$ has a reddish brown paste, brown slip glazed exterior, and unglazed interior. It may be a piece of tile. The sherd from MG 5B has a salt glaze exterior with a brown Albany slip interior. The remaining sherd has a Bristol glaze exterior with a thin brown slip glazed interior. Bristol glaze dates after 1884 (Greer 1981:210).

\section{Porcelain}

This is approximately one-half of a porcelain furniture castor.

METAL

This category consists of nine cut nails, three wire nails, and five pieces of miscellaneous metal. The miscellaneous group contains two fragments of a cast iron kettle lid (?), one heavy fragment of unidentified machinery, and two unidentifiable fragments.

Cut nails, apparently a New World invention (Noel-Hume 1970:254), were perfected about 1790 and continued being used into the early twentieth century, especially on the frontier. Wire nails were perfected in Europe in the mid nineteenth century and came into general use after 1875.

GLASS

A total of 33 fragments of glass were recovered from 41TT310. The largest group consists of olive green wine bottle fragments, one with a kick-up.

Two medicine bottle fragments are included. One of these is an amethyst panel bottle base dating between 1880 and 1925 (Newman 1970). The other is an aqua blown-in-mold bottle with a partial raised mark which is too incomplete to identify. Both of these specimens are from Test Pit B with the aqua fragment recovered from Level 2 and the amethyst from Level 6.

Three fragments of bitters bottles were also recovered. Although not enough is present to make a positive identification, one of these fragments is reminiscent of a log cabin bitters bottle, such as the "St. Brakes $1860 \mathrm{X}$ Bitter" (Sellari and Sellari 1975).

Other identifiable materials include three snuff bottle fragments from MG 5A, four aqua specimens, two fruit jars, two soda bottles from MG 5B, and one olive panel bottle fragment from MG 6 . 
The remaining glass is unidentifiable. These 11 fragments consist of 5 clear, 3 brown, 2 amethyst, and 1 amber.

OTHER

Included here are 1 unidentifiable button and 15 brick fragments. The button was found in MG 5B, and the brick fragments were recovered from Test Pit $\mathrm{S}$.

Nonartifactual Remains

Categories of materials discussed in this section are wattlemimpressed daub, burned clay, burned and unburned bones, mussel shells, burned rocks, and silicified wood chunks. The distribution of these remains is shown in Table 5. Most of these materials are thought to be the by-product of human activity at 41TT310, with the silicified wood chunks and the burned clay being the most problematical.

DAUB

A total of 38 very small pieces of wattle-impressed daub were recovered from the excavations. Almost one-half (47\%) were found in Test Pit $P_{i} 50 \%$ were recovered from Test Pits $A, B, E$, and $F$. Although present only in small amounts, this daub does suggest that grasscovered structures may have been present in the northeastern and southern portions of the site at some point during the Caddoan occupation.

BURNED CLAY

This category includes fragments of burned clay which could not be placed into a more distinctive group (e.g., daub or eroded sherds). These specimens appear to reflect burning, but the activities resulting in this burning (e.g., prehistoric hearths, historic land clearing) remain unknown. A total of 145 pieces of burned clay were identified. Ninetyone $(63 \%$ of the total) were found in Test Pits $A, B, E$, and $F$ in the southern part of the site; $17 \%$ came from the northeastern part of the site in Test Pits $N$ and P. This horizontal clustering roughly matches that of the daub.

UNBURNED BONES

The total of 16 pieces of unburned bones includes 8 fragments from the upper three levels of Test Pit P. There are indications that most of these eight are parts of a single bone, possibly a split metapodial tool. None of these specimens can be identified to genus or species.

BURNED BONES

The seven burned bone fragments cluster in the southern and northeastern portions of the site. All of these are small and unidentified. 


\begin{tabular}{|c|c|c|c|c|c|c|c|}
\hline \multirow[b]{2}{*}{ Provenience } & \multicolumn{7}{|c|}{$\begin{array}{r}\text { TABLE } 5 \\
\text { PROVENTENCE OF NONARTTFACTUAL, REMATNS }\end{array}$} \\
\hline & Daub & $\begin{array}{l}\text { Burned } \\
\text { Clay }\end{array}$ & $\begin{array}{l}\text { Unburned } \\
\text { Bones }\end{array}$ & $\begin{array}{l}\text { Burned } \\
\text { Bones }\end{array}$ & $\begin{array}{l}\text { Mussel } \\
\text { Shell } \\
\text { Fragments }\end{array}$ & $\begin{array}{l}\text { Burned } \\
\text { Rocks }\end{array}$ & $\begin{array}{l}\text { Silicified } \\
\text { Wood } \\
\text { Chunks }\end{array}$ \\
\hline \multicolumn{8}{|l|}{ TEST PIT A } \\
\hline Level 1 & 2 & - & - & - & - & - & 1 \\
\hline Level 2 & - & - & - & - & - & - & - \\
\hline Level 3 & - & - & - & - & - & - & 1 \\
\hline Level 4 & - & 1 & - & 1 & - & - & 1 \\
\hline Level 5 & $=$ & $\underline{5}$ & $=$ & $=$ & $=$ & $=$ & $\underline{1}$ \\
\hline Subtotals & $\overline{2}$ & $\overline{6}$ & $\overline{0}$ & $\overline{1}$ & $\overline{0}$ & $\overline{0}$ & 4 \\
\hline \multicolumn{8}{|l|}{ TEST PIT B } \\
\hline Level 1 & 1 & 4 & - & - & 3 & - & - \\
\hline Level 2 & 6 & 18 & - & 2 & $2^{*}$ & - & 1 \\
\hline Level 3 & 4 & 8 & - & - & - & - & 1 \\
\hline Leve1 4 & - & 7 & 1 & - & 2 & - & 1 \\
\hline Level 5 & - & 4 & - & - & - & - & 5 \\
\hline Leve1 6 & 1 & - & - & - & - & - & 2 \\
\hline Level 7 & - & 1 & - & - & - & - & 2 \\
\hline Leve1 8 & $=$ & - & $=$ & $=$ & $=$ & $=$ & 1 \\
\hline Subtotals & $\overline{12}$ & $\overline{42}$ & $\overline{1}$ & $\overline{2}$ & $\overline{7}$ & $\overline{0}$ & $\overline{13}$ \\
\hline \multicolumn{8}{|l|}{ TEST PIT C } \\
\hline Level 1 & - & - & - & - & 1 & - & 1 \\
\hline Level 2 & $=$ & $=$ & $=$ & $=$ & $=$ & $=$ & $\underline{0}$ \\
\hline Subtotals & $\overline{0}$ & $\overline{0}$ & $\overline{0}$ & $\overline{0}$ & $\overline{1}$ & $\overline{0}$ & $\overline{1}$ \\
\hline TEST PIT D & 0 & 0 & 0 & 0 & 0 & 0 & 0 \\
\hline \multicolumn{8}{|l|}{ TEST PIT E } \\
\hline Level 1 & 1 & 3 & - & - & 1 & - & - \\
\hline Level 2 & - & - & - & 1 & - & - & - \\
\hline Leve1 3 & 1 & 4 & - & - & - & - & - \\
\hline Level 4 & - & 3 & 1 & - & - & 1 & - \\
\hline Level 5 & 1 & 5 & - & - & - & 1 & - \\
\hline Level 6 & $\underline{1}$ & 3 & $=$ & $=$ & $=$ & $=$ & 1 \\
\hline Subtotals & $\overline{4}$ & $\overline{18}$ & $\overline{1}$ & $\overline{1}$ & $\bar{I}$ & $\overline{2}$ & $\overline{1}$ \\
\hline \multicolumn{8}{|l|}{ TEST PIT F } \\
\hline Leve1 1 & - & 1. & - & - & - & - & - \\
\hline Level 2 & - & 7 & - & 1 & 3 & - & - \\
\hline Level 3 & 1 & 4 & - & - & - & - & - \\
\hline \multicolumn{8}{|c|}{ *One of these two is burned. } \\
\hline
\end{tabular}


Table 5, continued

\begin{tabular}{|c|c|c|c|c|c|c|c|}
\hline \multirow[b]{2}{*}{ Provenience } & \multirow[b]{2}{*}{ Daub } & \multirow[b]{2}{*}{$\begin{array}{l}\text { Burned } \\
\text { Clay }\end{array}$} & \multirow[b]{2}{*}{$\begin{array}{l}\text { Unburned } \\
\text { Bones }\end{array}$} & \multirow[b]{2}{*}{$\begin{array}{l}\text { Burned } \\
\text { Bones }\end{array}$} & \multirow{2}{*}{$\begin{array}{l}\text { Mussel } \\
\text { Shell } \\
\text { Fragments }\end{array}$} & \multirow[b]{2}{*}{$\begin{array}{l}\text { Burned } \\
\text { Rocks }\end{array}$} & \multirow{2}{*}{$\begin{array}{l}\text { Silicif } \\
\text { Wood } \\
\text { Chunks }\end{array}$} \\
\hline & & & & & & & \\
\hline \multicolumn{8}{|c|}{ TEST PIT $F$, cont'd. } \\
\hline Leve1 4 & - & 3 & 1 & - & - & 1 & - \\
\hline Leve1 5 & - & 10 & - & - & - & - & 1 \\
\hline Level 6 & - & 1 & - & - & - & - & 1 \\
\hline Level 7 & - & - & - & - & - & - & 4 \\
\hline Level 8 & $=$ & $\underline{2}$ & $=$ & $=$ & $=$ & $\underline{1}$ & $=$ \\
\hline Subtotals & $\overline{1}$ & $\overline{28}$ & $\overline{1}$ & $\overline{1}$ & $\overline{3}$ & $\overline{2}$ & $\overline{6}$ \\
\hline \multicolumn{8}{|l|}{ TEST PIT $\mathrm{G}$} \\
\hline Level 1 & - & 2 & - & - & - & - & 2 \\
\hline Level 2 & - & 5 & - & - & - & - & - \\
\hline Level 3 & - & - & - & - & - & - & - \\
\hline Level 4 & $=$ & $=$ & $=$ & $=$ & $\underline{1}$ & $=$ & $\underline{1}$ \\
\hline Subtotals & $\overline{0}$ & $\overline{7}$ & $\overline{0}$ & $\overline{0}$ & $\overline{1}$ & $\overline{0}$ & $\overline{3}$ \\
\hline \multicolumn{8}{|l|}{ TEST PIT H } \\
\hline Level 1 & - & - & - & - & - & - & - \\
\hline Level 2 & - & - & - & - & - & - & - \\
\hline Level 3 & - & - & - & - & - & - & - \\
\hline Level 4 & $=$ & $=$ & $=$ & $=$ & $=$ & $=$ & $\underline{1}$ \\
\hline Subtotals & 0 & 0 & 0 & $\overline{0}$ & $\overline{0}$ & $\overline{0}$ & $\overline{1}$ \\
\hline \multicolumn{8}{|l|}{ TEST PIT I } \\
\hline Level 1 & - & 1 & - & - & - & - & - \\
\hline Level 2 & - & - & - & - & - & - & - \\
\hline Level 3 & - & - & - & - & - & - & 1 \\
\hline Level 4 & - & - & - & - & - & 1 & 1 \\
\hline Level 5 & $=$ & $=$ & $=$ & $=$ & $=$ & $=$ & $=$ \\
\hline Subtotals & 0 & 1 & $\overline{0}$ & 0 & 0 & 1 & 2 \\
\hline \multicolumn{8}{|l|}{ TEST RIT J } \\
\hline Level 1 & - & - & - & - & - & - & 3 \\
\hline Level 2 & - & - & - & - & - & - & 2 \\
\hline Level 3 & - & - & - & - & - & - & 3 \\
\hline Level 4 & $=$ & $=$ & $=$ & $=$ & $=$ & $=$ & $=$ \\
\hline Subtotals & $\overline{0}$ & $\overline{0}$ & $\overline{0}$ & $\overline{0}$ & $\overline{0}$ & $\overline{0}$ & $\overline{8}$ \\
\hline TEST PIT $\mathrm{K}$ & 0 & 0 & 0 & 0 & 0 & 0 & 0 \\
\hline \multicolumn{8}{|l|}{ TEST PIT L } \\
\hline Level 1 & - & - & - & - & - & - & - \\
\hline Level 2 & - & 1 & - & - & - & - & 2 \\
\hline Level 3 & $=$ & $=$ & $=$ & $=$ & $=$ & $=$ & $=$ \\
\hline Subtotals & $\overline{0}$ & $\overline{1}$ & $\overline{0}$ & $\overline{0}$ & $\overline{0}$ & $\overline{0}$ & 2 \\
\hline
\end{tabular}


Table 5, continued




Table 5, continued

\begin{tabular}{|c|c|c|c|c|c|c|c|}
\hline \multirow[b]{3}{*}{ Provenience } & \multirow[b]{3}{*}{ Daub } & \multirow{3}{*}{$\begin{array}{l}\text { Burned } \\
\text { Clay }\end{array}$} & \multirow[b]{2}{*}{ Unburned } & \multirow{3}{*}{$\begin{array}{l}\text { Burned } \\
\text { Bones }\end{array}$} & \multirow{3}{*}{$\begin{array}{l}\text { Mussel } \\
\text { Shell } \\
\text { Fragments }\end{array}$} & \multirow{3}{*}{$\begin{array}{l}\text { Burned } \\
\text { Rocks }\end{array}$} & \multirow{3}{*}{$\begin{array}{l}\text { Silici } \\
\text { Wood } \\
\text { Chunks }\end{array}$} \\
\hline & & & & & & & \\
\hline & & & Bones & & & & \\
\hline \multicolumn{8}{|l|}{ TEST PIT $\mathrm{R}$} \\
\hline Leve1 1 & - & - & - & - & - & - & - \\
\hline Level 2 & $\underline{1}$ & $=$ & $=$ & $=$ & $=$ & $=$ & $=$ \\
\hline Subtotals & $\overline{1}$ & $\overline{0}$ & $\overline{0}$ & $\overline{0}$ & $\overline{0}$ & $\overline{0}$ & 0 \\
\hline \multicolumn{8}{|l|}{ TEST PIT $\mathrm{S}$} \\
\hline Level 1 & - & - & - & - & - & - & - \\
\hline Level 2 & - & - & - & - & - & - & - \\
\hline Level 3 & - & - & - & - & - & - & - \\
\hline Level 4 & - & - & - & - & - & - & 1 \\
\hline Leve1 5 & $=$ & $=$ & $=$ & $=$ & $=$ & $=$ & $=$ \\
\hline Subtotals & 0 & 0 & 0 & 0 & 0 & 0 & 1 \\
\hline \multicolumn{8}{|l|}{ TEST PIT T } \\
\hline Level 1 & - & 3 & - & - & - & - & 2 \\
\hline Level 2 & - & 6 & - & - & - & - & - \\
\hline Level 3 & $=$ & 1 & $=$ & $=$ & $=$ & $\underline{1}$ & $\underline{1}$ \\
\hline Subtotals & 0 & 10 & 0 & 0 & 0 & 1 & 3 \\
\hline \multicolumn{8}{|l|}{ TEST PIT U } \\
\hline Level 1 & - & - & - & - & - & - & 1 \\
\hline Level 2 & - & - & - & - & - & 1 & - \\
\hline Level 3 & - & - & - & - & - & - & - \\
\hline Level 4 & - & - & - & - & - & - & 3 \\
\hline Level 5 & $=$ & $=$ & $=$ & $=$ & $=$ & $=$ & $=$ \\
\hline Subtotals & 0 & 0 & 0 & $\overline{0}$ & 0 & $\overline{1}$ & 4 \\
\hline \multicolumn{8}{|l|}{ MOTOR GRADER } \\
\hline CUT $5 A$ & - & - & 4 & - & - & - & - \\
\hline CUT 5B & - & - & 1 & - & - & - & - \\
\hline MISCELLANEOUS & - & 4 & - & - & - & 1 & 2 \\
\hline TOTALS & 38 & 14.5 & 16 & 7 & 13 & 13 & 75 \\
\hline
\end{tabular}




\section{MUSSEL SHELLS}

Thirteen small, eroded slivers of mussel shells were recovered. One fragment from Level 2 of Test Pit B is burned.

BURNED ROCKS

Aside from the burned rocks that comprise Feature 1 in Test Pit I, only 13 other burned rock fxagments are apparent among the various lithic materials collected. Table 5 shows that there is no horizontal clustering. Most are of quartzite, and they are identified mainly by angular fractures. Some of the numerous small ferruginous sandstone fragments that occur in the soil throughout the site could be burned, but they cannot be identified as such with confidence.

\section{SILICIFIED WOOD CHUNKS}

Silicified wood is one of the materials utilized prehistorically in East Texas for the production of tools, but because of the structure of the material, the debitage frequently does not exhibit typical flake characteristics. Thus, it is impossible to distinguish much of the culturally modified silicified wood from tabular chunks that naturally occur in the soils in the area. While those silicified wood artifacts having flake characteristics are included with the chipped stone debitage, 75 pieces are placed with the nonartifactual remains. The distribution of the silicified wood chunks generally matches that of the combined chipped stone categories, suggesting that most of the silicified wood chunks are associated with prehistoric occupation of the site. For example, Test Pits A, B, E, F, N, and $P$ have $58 \%$ of the total chipped stone debitage and an equal percentage of the silicified wood chunks. Elsewhere, Test Pit $J$ contained $10 \%$ of both the chipped stone debitage and the silicified wood chunks.

\section{Assessment of Historic Component}

The primary conclusion that can be reached about the historic component at 41 TT310 is that the location of Fort Sherman remains unidentified. When Traylor Russel (1965) wrote the history of Titus County, he believed that the fort was located to the west of FM 21 on the Celia Coots Survey, which lies west of the F. W. Benson Survey (see Fig. 2). As previously mentioned, the field notes of the 1841 Coots Survey state that the land is "near Fort Sherman" (General Land office 1841), implying that the fort was not on these surveyed lands and that fort structure(s) were still visible.

Celia Coots assigned another 320 acres to Andrew Coots in February of 1842 (General Land Office 1842). This survey, which is described as being "west of Fort Sherman," is about $3 \mathrm{~km}$ north of the 1841 Celia Coots survey (see Fig. 2). Just what "west of Fort Sherman" means in this context is unclear. If the fort was on the first Coots Survey or the Jesse Benson Survey to the east, then the 1842 Coots Survey is more north than west of the fort. 
Throughout the early twentieth century, land transactions repeatedly referred to the 1841 Coots Survey as the "Fort Sherman Place." In 1904 I. C. and Evline Garretson sold to A. A. Taylor 3.39 acres (Titus County Deed Record). This parcel is described as "being situated in the N.E. corner of the east half of a tract of land known as the Ft. Sherman place." Forty feet of the northeast corner of this place was on the "Leesburg and old Gray Rock road."

In 1918 Eugene and Edna Morris sold 61.75 acres, which was described as being "the south part of the East half of tract of land upon the holding of Celia Coots and known as the Ft. Sherman Place..." (Titus County Deed Record). Later transactions on this survey continue to use the phrase "known as the Fort Sherman place." This name may have come into use because a log house once stood on the property and was known locally as Fort Sherman. It was torn down in 1967, and some of the better logs were used in the construction of a small $\log$ house on the west side of present-day FM 21 (see Fig. 3). Virginia Pickens McBride had an antique shop there for a short time. Russell, in a 1967 correction to his book, states that the log house was built between 1875-1880. In 1967 he spoke with H. W. Pickens, who was then 80 years of age. Mr. Pickens stated that some of the old-time residents believed that the fort was on the Jesse Benson Survey about 100 yards south of Pickens' rock house (see Fig. 3). This would put the location of the fort on the west side of FM 21 if Mr. Pickens was thinking in terms of due south, about where the log house presently stands. Pierce $(1969: 158)$ states that the fort stood on the east side of the Cherokee Trail crossing over Cypress Creek, which was near the 1969 FM 21 bridge over Cypress Creek. The road has been changed somewhat since 1969, and it is difficult to tell from old maps precisely where the old crossing was. Some maps indicate that the early road was west of the modern road, and Virginia P. McBride remembers her mother speaking of a road which trended southwest from the vicinity of the Pickens rock house (see Fig. 3 ).

It has been suggested by a number of local residents that the fort was on what is now park property and on the F. W. Benson Survey. If the fort had been 100 yards southeast, rather than south, of Pickens' house, the fort location would have been near the line between the two Benson surveys on the east side of present-day FM 21 (see Fig. 3 ). If this was the location, however, there must have been nothing left of the fort by 1854 when the Benson surveys were made since no mention was made of it in the survey notes.

No unequivocal evidence of the fort was found in the archeological testing at 41 Tr310. Such evidence would consist of the remains of a stockade (although there is no clear evidence that it had one) such as trench or post-hole molds and artifacts of a military nature. Years of plowing at 41 TT310 could have obliterated evidence of stockades or posthole molds, but no artifacts related to the military were found. At present, it appears the fort may have been located near FM 21, but it is not known precisely where.

Some archeological evidence was found, however, of an occupation dating perhaps as early as the mid nineteenth century (see Fig. 8). Several pieces of ceramics date to the mid nineteenth century or somewhat earlier. These were found in Test Pit $J$ and MG 5B and suggest that Frank W. Benson's house may have been on the sandy ridge near MG $5 \mathrm{~A}$ and MG $5 \mathrm{~B}$ (see Fig. 3). More than $40 \%$ of the historic artifacts were found in this area; it is near a spring and near a place where persimmon trees, which thrive in disturbed areas, used to grow (Virginia Pickens McBride, personal communication 1983).

On the other hand, there are a few artifacts in the collection (the hard-paste earthenware sherds, the amethyst panel bottle glass, and the Bristol glaze stoneware) which 
most likely post-date the Civil War and which may post-date Frank W. Benson's ownership of the property. These materials could relate to a turn-of-the-century occupation by the Miller family or some undocumented mid to late nineteenth-century occupation by $T$. H. Miller or others.

Assessment of Prehistoric Components

Site Formation Processes

As discussed previously in this chapter, the zonation observed in the soils at site 41TT310 reflects soil development rather than natural or cultural stratigraphy. This apparent lack of substantial soil deposition is not surprising in view of the site's upland setting and the fact that the landform containing 41 TT310 rises some $18 \mathrm{~m}$ above the floodplain of Big Cypress Creek (prior to inundation by Lake Bob Sandlin). Given that the site is not in an alluvial depositional environment and assuming that eolian deposition has not been a major factor in the geomorphic history of the site area, it becomes necessary to explain how cultural materials have become distributed vertically throughout the $\mathrm{A}$ horizon, sometimes to depths of 70 or $80 \mathrm{~cm}$.

The simplest and most economical explanation for this distribution, following Brown (1975), is that artifacts tend to move downward in sandy soils over time due to bioturbation. Using data from the Cox Site in Hopkins County, Brown (1975) shows that Archaic and Late Prehistoric occupations occurred on a single stable surface but that, because the Archaic artifacts had a longer period of time to settle downward into the site soils, the older materials tended to occur deeper than the Late Prehistoric materials.

Consistent with Brown's model, the artifacts at site 41 TT310 usually are most frequent in the uppermost level and decrease in frequency with depth (Fig. 9a and b). In areas where the B horizon occurs not far beneath the ground surface, a different pattern can sometimes be seen where artifacts migrate down through the $\mathrm{A}$ horizon and accumulate at the top of the dense B horizon (Fig. 9c). As discussed below, the notion that older artifacts will tend to occur deeper at sites such as 41TT310 simply because older materials have been on the site longer is one of the bases for arguing that an Archaic component is present at site 41TT310. Also, multicomponency may help to explain differences in vertical distributions such as those shown in Figure $9 \mathrm{a}$ and b. In this example, the southern portion of the site (Fig. 9a), with its steadily decreasing artifact frequencies with depth, appears to have Archaic and Caddoan components (see Chronology). This contrasts with the pattern shown for Test Pit P (Fig. 9b) where artifact frequencies decrease dramatically below Level 3 and where an Archaic component cannot be identified.

\section{Chronology}

The small size of the prehistoric artifact sample and the lack of stratified deposits make interpretation of the prehistoric chronology difficult. Most obviously, the site has one or more Caddoan components. Dating this Caddoan occupation(s) is problematical, however, since none of the sherds recovered from the site can be typed with confidence. The 


\section{ARCHEOLOGICAL TESTING AT 41 TT3IO} LAKE BOB SANDLIN STATE PARK

VERTICAL DISTRIBUTION OF COMBINED LITHIC DEBITAGE \& CERAMICS SELECTED TEST PITS

a) Test Pits $A, B, C, D, E, F \& Q$

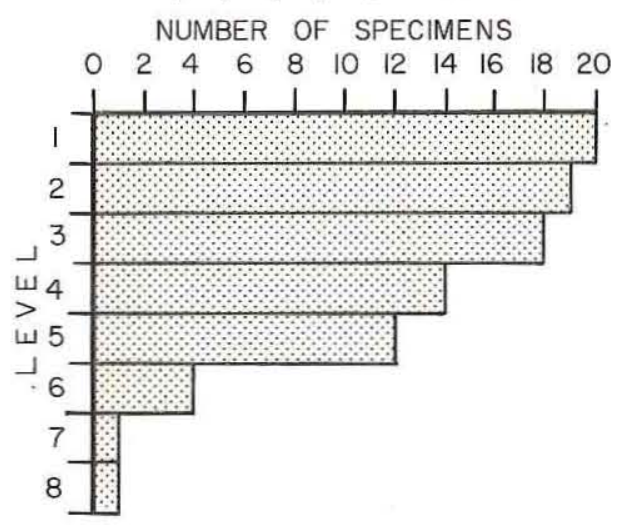

b) Test pit $\mathrm{P}$



c) Test Pit G

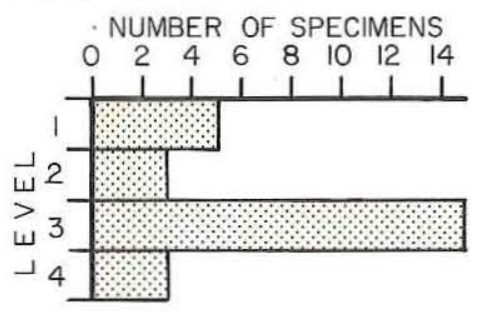


nature of the ceramic collectjon, with plain sherds predominating (64\%) and brushed sherds present only in small numbers $(9 \%)$, suggests that most of the Caddoan component may date to Thurmond's (1981:438) Transitional Early to Late Caddoan Period (A.D. 1400-1500). On the other hand, the presence of a few punctated body sherds and rim sherds with horizontal incised lines hints that occupation may have occurred also during Thurmond's (1981:435-436) Early Caddoan Period 1 (A.D. 800-1200). In short, the ceramics suggest that the Caddoan component may represent multiple occupations, a situation which certainly is conmon in the project region and not at all unexpected for site 41TT310. Efforts to isolate these multiple Caddoan occupations through studying the horizontal and vertical distributions of surface treatment groups (e.g., brushed sherds versus punctated body sherds) and temper categories (i.e., grog tempered versus grog and bone tempered) have been unsuccessful, perhaps in part because of small sample sizes.

Evidence for a second prehistoric component at 41TT310, possibly middle Archaic, consists of (1) a Neches River dart point from Level 7 of Test Pit $F$ at the southern end of the site, and (2) the different vertical distributions of lithics and ceramics in the southern portion of the site (Fig. 10). Figure 10 shows that in the southern site area lithics occur in roughly equal frequencies in Levels 1 through 5 but that ceramics are heavily concentrated in the upper three levels and are absent below Level 5 . Using the idea that older materials may occur deeper within a nonaggrading sandy site due to the downward migration of artifacts, the data shown in Figure 10 are taken as suggesting that a pre-Caddoan occupation is represented. The tenuous temporal assessment of this component as middle Archaic is based on the presence of the Neches River dart point, which in other contexts has been assigned to the middle Archaic period (Prewitt 1974:11).

Evidence for a third prehistoric component, conceivably represented by the single Gary dart point, is even more tenuous. This dart point was recovered from a level beneath most (81\%) of the sherds in Test Pit P. A few sherds (7\%) were found in the same level as the projectile point, and several others (12\%) were recovered from deeper levels. Recent investigations at the Deshazo Site in Nacogdoches County indicate that Gary dart points cluster with sandy paste pottery and, at least at Deshazo, may relate mostly to Early Ceramic period occupations rather than to Late Prehistoric Caddoan occupations (Girard 1982:336). However, the lack of sandy paste or Williams Plain pottery at 41TT310 fairly convincingly argues against an Early Ceramic occupation at this site. Also, Young (1981: 65) presents evidence from a site on Tankersley Creek, just $11 \mathrm{~km}$ from 41TT310, which suggests that small Gary dart points may occur in Caddoan contexts in the project region.

Nature of the Occupations

The purpose of this section is to review the kinds and distributions of material remains encountered at 41 TT310 in order to assess the duration of site occupations and the types of activities represented. As an aid in making interpretations, comparisons are made where possible to 41TT110, a nearby site that has been more thoroughly investigated.

Archeological materials relating to the prehistoric components at 4111310 occur over most of the $380-\mathrm{by}-85-\mathrm{m}$ site area.* In terms of the specific prehistoric components, the

*This site boundary, as shown in Figure 4, encompasses all test pits yielding four or more artifacts. Pits yielding fewer than this number are considered to be effectively beyond the limits of the site. 


\section{ARCHEOLOGICAL TESTING AT 4ITT3IO LAKE BOB SANDLIN STATE PARK VERTICAL DISTRIBUTION OF ARTIFACTS TEST PITS A, B, C, D, E, F \& Q}

a) Lithic Debitage

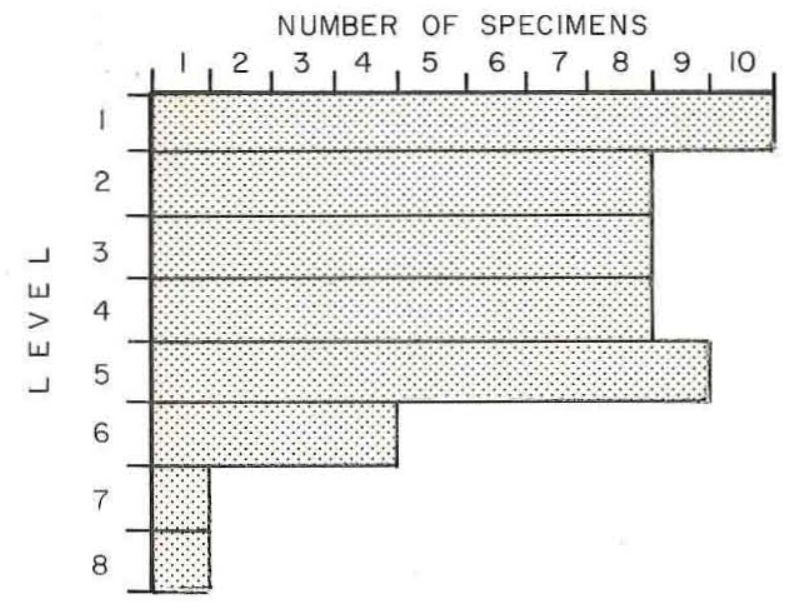

b) Ceramics

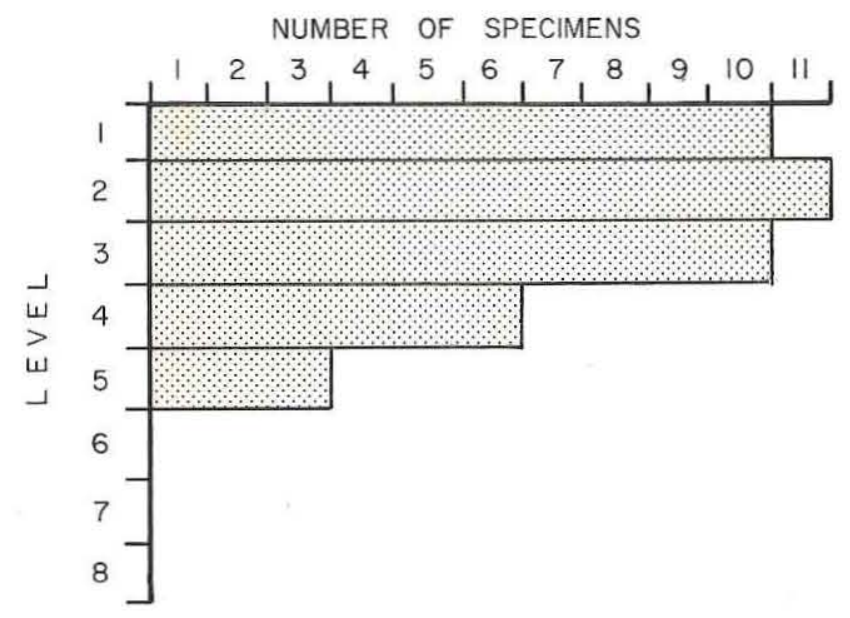


horizontal extent of the Archaic occupation remains uncertain since it can be isolated with reasonable confidence only at the southern end of the site. It should be noted, though, that the relatively high frequency of lithics (30 lithics versus 3 sherds) in Test Pits $J_{\text {, }}$ $I_{1}$, and $T$ does suggest that the Archaic component may be represented also in the northwestern part of the site. In any case, the sparseness of materials assignable to the Archaic component precludes meaningful statements about artifact distributions and ranges of activities. On a very general level, however, this sparseness of materials does suggest that 41 TT310 was used infrequently and nonintensively. It seems most likely that utilization of 41 TT310 during the Archaic was by small groups and for short periods of time.

The distribution of Caddoan ceramics indicates that Late Prehistoric peoples made use of the entire site area. There are, however, dramatic differences in artifact densities between parts of the site indicating different use histories. The northeastern site area (sampled by Test Pits $\mathrm{N}$ and P) contains relatively high artifact densities (averages of 39 sherds $/ \mathrm{m}^{2}$ and 26 lithics $\left./ \mathrm{m}^{2}\right)$ * and was clearly the primary locus of Caddoan occupation. Elsewhere, artifact densities, though variable, are consistently moderately low or very low (averages of 3.3 sherds $/ \mathrm{m}^{2}$ and 7.9 lithics $/ \mathrm{m}^{2}$ )* indicating infrequent and/or nonintensive use. Although there are no available data on the density of ceramics at 41TT110, data from Flaigg's $(1982: 67)$ thesis indicate that the average density of lithic debitage (43.6 pieces $/ \mathrm{m}^{2}$ ) in the Late Prehistoric units at 41 TT110 is much greater than that anywhere at 41TT310. This intimates that the Caddoan occupation at $41 T T 110$ was more intensive than that at 41 TT310 and suggests that the former (41TT110) represents residential use and the latter (41TT310) represents short-term, nonresidential use. On the other hand, the density data from 41 TT110 are from a unit which sampled a Caddoan midden where densities are expected to be high. For example, investigations at the Deshazo Site, a late Caddoan hamlet or small village in Nacogdoches County, have shown that artifact densities can vary considerably within a site, ranging in the case of Deshazo from 17 sherds $/ \mathrm{m}^{2}$ in plaza or outside activity areas, to about 30 sherds $/ \mathrm{m}^{2}$ in areas with structures, to almost $150 \mathrm{sherds} / \mathrm{m}^{2}$ in midden areas (Fields 1981:112-117; Creel 1982:42-44). Viewed from this perspective, the density data from 41 TT310 suggest that one part of the site -- that is, the northeastern portion -- indeed may have been used with considerable frequency or intensity. With the data presently available, it is impossible to ascertain just how this high density area relates to the rest of the site; for example, whether the low density areas represent activity areas associated with the main site area or whether the low density areas represent repeated, short-term use not associated with the occupation of the high density part of the site.

Examination of the artifacts and nonartifactual remains recovered, although not yielding conclusive evidence, does offer some clues as to the range of activities carried out at the site during the Caddoan occupation(s). The presence of wattle-impressed daub, albeit in very small quantities, at the northeastern and southern ends of the site suggests that some sort of structures may have been used. Even though these need not have been residences and thus may not represent year-round residential use, structures would indicate an investment of effort that might not be expected at ephemerally used sites.

*These averages do not include sherds labeled as Too Small or Fragmented since these are often excluded from ceramic analyses. Averages for lithics combine all lithic tools and debitage. 
The evidence does suggest, though, that the range of activities carried out, particularly in the northeastern portion of the site, was quite limited. Most notably, the ceramics appear to be almost entirely restricted to jar forms, and there is a remarkable scarcity of cores and stone tools such as projectile points, bifaces, drills/perforators, unifaces, utilized flakes, hammerstones, and grinding implements. In fact, the only nonceramic artifacts recovered from the northeastern site area are one dart point, a reworked celt fragment (possibly a hammerstone), a possible abrader, a possible bone tool, and cortical and interior flakes. Interestingly, most of the stone tools ( 9 of 12) were found in parts of the site other than the main (northeastern) site area or even in pits considered to be beyond the limits of the site.

All in all, the data suggest that the northeastern part of the site saw fairly intensive use but for a limited range of activities. This use was likely nonresidential and perhaps involved short-term (as little as one week or as much as one month?) encampments by small social or task groups focusing on the procurement or processing of specific resources. The Caddoan occupation of the low density site area appears to have been yet more ephemeral, perhaps involving overnight or very short-term encampments of small social or task groups en route to resource procurement areas. 



\title{
CHAPTER 6
}

\section{SUMMARY AND RECOMMENDATIONS}

\author{
Project Summary
}

Archeological investigations at 41TT310, which is located within the proposed Lake Bob Sandlin State Park in southwestern Titus County, Texas, were conducted under the sponsorship of the Texas Parks and Wildlife Department. The purposes of the work were to (1) determine whether or not the site is the location of a Republic of Texas-era fortification called Fort Sherman, and (2) assess the significance of the northern and eastern portions of the site which were to be impacted by park development. The project consisted of a literature and records search, test excavations, and analysis of information gathered.

Site 41 TT310 was recorded by TPWD archeologists during archeological survey and machine-testing of the southwestern portion of the proposed state park. These investigations produced evidence of a prehistoric Caddoan component and a nineteenth-century AngloAmerican component. The site was initially assessed as having a high research potential because several of the historic artifacts appeared to date potentially as early as the era of a Republic of Texas fort called Fort Sherman. Earlier investigations (Sullivan n.d.:39) had indicated that this fortification should be located somewhere within or near the southwestern end of the proposed state park.

In November 1983, Prewitt and Associates, Inc. entered into a contractual agreement with the TPWD to conduct further investigations at 41TT310 before park development planning proceeded. Prewitt and Associates, Inc. personnel carried out the test excavations and wrote all parts of this report except those relating to the historic component. Data on the historic component has been gathered, analyzed, and reported by personnel from the Institute of Applied Sciences, North Texas State University.

The archival research consisted of (1) reviewing maps, deed records, survey patents, and various published and unpublished sources, and (2) interviewing persons living in the project area. Tasks accomplished during the testing of the site included: (1) excavating 21 1-by-1-m units in 10-cm-thick levels and screening the fill through 1/4-inch-mesh hardware cloth; (2) plotting the location of the test pits on a 2-ft contour map provided by TPWD; (3) profiling and photographing one wall of each test pit; and (4) documenting the investigations with excavation level forms, profile notes, daily journal, and photographs.

The archival research and field investigations could not resolve the question of the location of Fort Sherman. The literature search revealed that references to the location of the fort are ambiguous but that it may be situated within or near the proposed Lake Bob Sandlin State Park. Machine stripping conducted in August 1983 by TPWD archeologists and test excavations conducted by Prewitt and Associates, Inc. did not identify any structural remains that may be part of the fort complex. Historic artifacts recovered during the survey and testing are few in number $(\mathrm{N}=117)$ and suggest mid to late nineteenth century occupation.

The excavation of the 21 test pits produced evidence of prehistoric utilization of most of the $380-\mathrm{by}-85-\mathrm{m}^{2}$ site area. Generally, the density of prehistoric materials is low 
as only 12 stone tools, 151 pieces of lithic debitage, and 208 ceramic sherds were found. Nonartifactual prehistoric debris includes small amounts of wattle-impressed daub, burned clay, mussel shell fragments, burned rocks, and burned and unburned bone fragments. Only one cultural feature, a cluster of burned rocks that appears to represent the remnants of a hearth, was uncovered.

The analysis of the prehistoric artifact collection suggests that Archaic and Caddoan components are represented. Materials in the sandy A horizon soil, which averages $42 \mathrm{~cm}$ in thickness, have been mixed by bioturbation to the extent that it is difficult to separate these components. The Archaic component can be isolated with confidence only in the lower levels at the southern end of the site. The evidence for an early component consists of a Neches River dart point fragment of probable middle Archaic age and a small amount of debitage. The high relative frequency of lithics at the northwestern end of the site suggests that most of the materials in this part of the site may relate also to the Archaic occupation. The existing sample of materials from the Archaic component indicates a very limited use of the site during this period.

The second prehistoric component is identified by the occurrence of Late Prehistoric Caddoan ceramics across most of the site. Unfortunately, the ceramic sample consists of only 149 sherds that are large enough to analyze, and none of these can be assigned with confidence to known types and thus to specific time periods. There are, however, suggestions in the ceramic collection of Transitional Early to Late Caddoan and Early Caddoan Period 1 occupations.

As with all other artifactual categories, the ceramics are most common in the upper levels of the test pits. The size of the Caddoan artifact collection indicates that use of the site during Late Prehistoric times was more intense than that during the Archaic. The horizontal distribution of cultural materials shows that the northeastern part of the site was the primary locus of Caddoan occupation. Other parts of the site where the density of artifacts is low may have served as activity areas associated with the main site area or may represent shorter term use not associated with the occupation of the northeastern site area.

The association of two clusters of wattle-impressed daub with the Caddoan component suggests that grass-covered structures may have been present and thus that utilization of the site, while not necessarily residential, was more than of an ephemeral nature. The limited variety of artifact types recovered indicates that, while the occupation of the northeastern site area may have been moderately intensive, it was for a limited range of activities, possibly for the procurement or processing of specific resources.

\section{$\underline{\text { Recommendations }}$ \\ Research Potential}

Analysis of the data gathered during the investigations at 41T1310 indicates that the site is eligible for nomination as a State Archeological Landmark and that it is potentially eligible for nomination to the National Register of Historic Places under Criterion D. This assessment is based on the high research potential exhibited by the prehistoric 
components represented at the site. The historic component is judged to have a low research potential, at least with the data presently available, because (1) the location of Fort Sherman cannot be identified, (2) the nature and associations of the historic component cannot be identified in historical records, and (3) the lack of identifiable features (structural remains, trash deposits, etc.) and the paucity of artifacts suggest that the site would be difficult to interpret using archeological data.

Conversely, the site is judged to have the potential to yield significant information towards understanding the prehistory of the Cypress Creek drainage. Most importantly, data from 41 TT310 could contribute to reconstructing settlement systems for the area. Within a $3.2-\mathrm{km}$ radius of 41 TT310, Thurmond (1981:215) has identified only two middle Archaic "limited use areas" (at sites 41 CP19 and 41CP33) and three middle Archaic "heavy use areas" (at 41CP14, 41TT110, and 41TT119). Site 41CP33 is the only one of these five that has not been inundated by Lake Bob Sandlin. Thus, any information recovered from 41 TT310 concerning the kinds of activities carried out at middle Archaic sites (in this case a "limited use area") would increase our understanding of Archaic settlement and subsistence strategies.

A more easily realized potential exists for relating the Caddoan component to local Late Prehistoric settlement systems because the quantity of data relating to this component is greater than that for the earlier component and because the ceramics show bints of an occupation contemporaneous with that at 41TT110. Artifacts and features uncovered in additional excavations at 41 TT310 could provide data on the range of activities carried out, and perhaps on social group size, which could be compared to information from 41 TT110 and used to reconstruct settlement and land-use strategies for at least one part of the Late Prehistoric period.

Park Development

As originally proposed, development of the southwestern part of Lake Bob Sandlin State Park would adversely impact portions of 41TT310. Specific park facilities within the site boundaries would consist of: (1) a parking lot in the north-central part of the site in the area of Test Pits C, D, and I; (2) approximately 16 picnic tables at the far northeastern end of the site around Test Pits $N$ and $P ;$ and (3) two hiking trails passing through the northwestern, northeastern, and lower central portions of the site.

Other facilities which are slated to be near the perimeter of the site include a park entrance road which will curve around the southern and southeastern flanks of the site and a comfort station, playground, and picnic tables which will be placed in the area that includes Test Pits $K$ and $U$ and Backhoe Trenches 2 and 3.

Because of the potential significance of 41TT310, it is recommended that the parking lot and those picnic tables in the vicinity of Test Pits $N$ and $\mathrm{P}$ be moved to alternate locations beyond the site boundaries. The parking lot could be moved to the southeast of the originally proposed location to a position south or southeast of the playground. Backhoe Trenches 2 and 3 revealed no cultural materials here, and Test Pits $H, K$, and $U$ showed an extremely diffuse artifact scatter. Also, all picnic tables which were to be placed in the vicinity of Test Pits $N$ and $P$ should be moved southward across the gully. 
It is recommended that the development of hiking trails be allowed to proceed as planned since there appears to be no feasible way for these trails to avoid the site unless plans for Park Area E are changed considerably. It is further recommended, however, that the trails be constructed (perhaps using a nongravel base) and maintained so that foot traffic will not cause erosion leading to the exposure of cultural materials. Also, the existing coastal bermudagrass that covers the site should be maintained since it will limit erosion and conceal surficial artifacts. Coastal bermudagrass or some other type of protective ground cover should be planted along the flanks of hiking trails in the vicinity of Test Pits $J, L$, and $T$ as vegetation on the northwestern end of the site presently is sparse. Finally, construction of all park facilities within or adjacent to the site should be monitored by an archeologist 
Anderson, Keith M.

1972 Prehistoric Settlement of the Upper Neches River. Bulletin of the Texas Archeological Society 43:121-197.

Anderson, Keith M., Kathleen Gilmore, Olin F. McCormick, III, and Pierre Morenon

1974 Archeological Investigations at Lake Palestine, Texas. Contributions in Anthropology 11. Southern Methodist University, Dallas.

Bell, Milton

1981 The Alex Justiss Site, a Caddoan Cemetery in Titus County, Texas. Publications in Archaeology Report 21. State Department of Highways and Public Transportation, Highway Design Division, Austin.

Blair, W. Frank

1950 The Biotic Provinces of Texas. The Texas Journal of Science 2(1):93-117.

Brown, Kenneth M.

1975 Time's Arrow and Postdepositional Disturbance. Paper presented at the 17th annual Caddo Conference, College Station, Texas.

Castenada, Carlos E.

1936 Our Catholic Heritage in Texas, 1519-1936, vol. I. Von Boeckmann-Jones Co., Austin, Texas.

Cliff, Maynard, Carol Carter, and Linda Verrett

1974 Archeological Survey of the Welsh Power Plant. Archaeology Research Program, Southern Methodist University, Dallas.

Creel, Darrell G.

1982 Site Description and Investigation. In The Deshazo Site, Nacogdoches County, Texas, vol. 1, edited by Dee Ann Story, pp. 35-50. Texas Antiquities Permit Series 7. Texas Antiquities Committee, Austin.

Davis, E. Mott

1958 The Whelan Site, a Late Caddoan Component in the Ferrell's Bridge Reservoir, Northeastern Texas. Report submitted to the National Park Service by The University of Texas at Austin, Division of Research in Anthropology

1970 Archaeological and Historical Assessment of the Red River Basin in Texas. In Archaeological and Historical Resources of the Red River Basin, edited by Hester A. Davis, pp. 25-65. Research Series 1. Arkansas Archaeological Survey, Fayetteville.

Duffield, Lathel F., and Edward B. Jelks

1961 The Pearson Site, a Historic Indian Site at Iron Bridge Reservoir, Rains County, Texas. Archaeology Series 4. Department of Anthropology, The University of Texas at Austin. 
Fenneman, Nevin M.

1938 Physiography of Eastern United States. McGraw-Hill Book Co., Inc., New York.

Fields, Ross C.

1981 Analysis of the Native Ceramics from the Deshazo Site, Nacogdoches County, Texas. M.A. thesis, The University of Texas at Austin.

Fisher, W. L.

1965 Rock and Mineral Resources of East Texas. Report of Investigations 54. Bureau of Economic Geology, The University of Texas at Austin.

Flaigg, Norman G.

1982 A Report on the Analysis of Lithic Material from the Benson's Crossing Site (41TT110), Titus County, Texas. M.A. thesis, The University of Texas at Austin.

General Land Office

1841 Celia Coots to Andrew Coots. November 12, field notes.

1842 Republic of Texas to Celia Coots. February 7, field notes.

1854a State of Texas to F. W. Benson. February 17, field notes.

1854b Deposition, Frank W. Benson. February 17.

Gilmore, Kathleen

1973 Caddoan Interaction in the Neches Valley, Texas. Ph.D. dissertation, Southern Methodist University, Dallas.

Girard, Jeffrey Scott

1982 The Chipped Stone Collection from the Deshazo Site (41NA27): A Technological, Functional and Typological Analysis. M.A. thesis, The University of Texas at Austin.

Goldschmidt, Walter R.

1935 A Report on the Archeology of Titus County in East Texas. Bulletin of the Texas Archeological and Paleontological Society 7:89-99.

Greer, Georgeanna H.

1981 American Stonewares, The Art and Craft of Utilitarian Potters. Schiffer Publishing Limited, Exton, Pennsylvania.

Griffith, William J.

1954 The Hasinai Indians of East Texas as Seen by Europeans, 1687-1772. Philological and Documentary Studies 11(3):41-168. Middle American Research Institute, Tulane University, New Orleans.

Gulick, C. A., Jr., and Winnie Allen

1924 The Papers of Mirabeau Buonaparte Lamar, vol. 4, part 1. Von Boeckmann-Jones Company, Austin, Texas. (Reprinted 1973).

Henry, Christopher D., and Joyce M. Basciano

1979 Environmental Geology of the Wilcox Group Lignite Belt. Report of Investigations 98. Bureau of Economic Geology, The University of Texas at Austin. 
Hsu, D. P.

1969 Appraisal of the Archaeological Resources of Titus County, Reservoir, Titus County, Texas. Archaeological Survey Report 4. Texas State Building Commission and Texas Water Development Board, Austin.

Hsu, Dick Ping, James V. Sciscenti, and S. Allen Skinner

1969 Appraisal of the Archaeological Resources of Big Cypress (Franklin County) Reservoir. Archaeological Survey Report 3. Texas State Building Commission and Water Development Board, Austin.

Jackson, A. T.

1934 Trenching of an Earth Mound, ‥ ‥ Hale Farm, Titus County, Texas. Intrainstitutional report of the University of Texas, Department of Anthropology, Austin.

Jelks, Edward B.

1965 The Archeology of the McGee Bend Reservoir, Texas. Ph.D. dissertation, The University of Texas at Austin.

Jelks, Edward B. (editor)

1967 The Gilbert Site. Bulletin of the Texas Archeological Society 37:1-248.

Johnson, LeRoy, Jr.

1962 The Yarbrough and Miller Sites of Northeast Texas with a Preliminary Definition of the La Harpe Aspect. Bulletin of the Texas Archeological Society 32:141-284.

Krieger, Alex D.

1946 Culture Complexes and Chronology in Northern Texas. University of Texas Publication No. 4640. Austin.

McCormick, Olin F., III

1973a Lake Swauano: An Archaeological Reconnaissance. Archaeology Research Program, Southern Methodist University, Dallas.

1973b Archaeological Resources in the Lake Monticello Area of Titus County, Texas. Contributions in Anthropology 8. Southern Methodist University, Dallas.

1974 Archaeological Excavations at Lake Monticello. Archaeology Research Program, Southern Methodist University, Dallas.

Miller, E. O., E. H. Moorman, and Edward B. Jelks

1951 Archeological Survey of Ferrell's Bridge Reservoir: Harrison, Marion, Upshur, Cass, Morris, Titus and Camp Counties, Texas. Report submitted to the U.S. Army Corps of Engineers by the National Park Service and the Smithsonian Institution River Basin Surveys.

Mount Pleasant Public Library, Mount Pleasant, Texas

Cemetery and genealogical records.

Newcomb, W. W., Jr.

1961 The Indians of Texas from Prehistoric to Modern Times. University of Texas Press, Austin. 


\section{Newman, T. Stell}

1970 A Dating Key for Post-Eighteenth Century Bottles. Historical Archaeology 4:7075.

Noel-Hume, Ivor

1970 A Guide to Artifacts of Colonial America. Alfred A. Knopf, New York.

1978 Pearlware: Forgotten Milestone of English Ceramic History. In English Pottery and Porcelain, edited by Paul Atterbury, pp. 42-49. Main Street Press, Clinton, New Jersey.

Norman-Wilcox, Gregor

1978 Staffordshire Ware in a Nutshe11. In English Pottery and Porcelain, edited by Paul Atterbury, pp. 166-170. Main Street Press, Clinton, New Jersey.

Pierce, B. C.

1932 Titus County: Its Background and History in Ante Bellum Days. M.A. thesis, University of Colorado, Boulder.

Pierce, Gerald S.

1969 Texas Under Arms, the Camps, Posts, Forts, and Military Towns of the Republic of Texas. Encino Press, Austin.

Prewitt, Elton R.

1974 Upper Navasota Reservoir: An Archeological Assessment. Research Report 47. Texas Archeological Survey, The University of Texas at Austin.

Price, Cynthia R.

1979 Nineteenth Century Ceramics in the Eastern Ozark Border Region. Monograph Series No. 1. Center for Archaeological Research, Southwest Missouri State University, Springfield.

Ramsey, John

1939 American Potters and Pottery. Colonial Press, Clinton, Massachusetts.

Russel1, Traylor

1965 History of Titus County. W. H. Morrison, Bookseller, Waco.

1967 Unpublished documents, Texas State Archives.

Sellari, Carlo and Dot Sellari

1975 The Illustrated Price Guide of Antique Bottles. Country Beautiful, Waukesha, Wisconsin.

Shafer, Harry J.

1977 Early Lithic Assemblages in Eastern Texas. The Museum Journal XVII:187-197. West Texas Museum Association, Lubbock.

Story, Dee Ann

1981 An Overview of the Archaeology of East Texas. Plains Anthropologist 26(92):139156. 
Suhm, Dee Ann, and Edward B. Jelks

1962 Handbook of Texas Archeology: Type Descriptions. Texas Archeological Society Special Publication 1 and Texas Memorial Museum Bulletin 4. Austin.

Suhm, Dee Ann, Alex D. Krieger, and Edward B. Jelks

1954 An Introductory Handbook of Texas Archeology. Bulletin of the Texas Archeological Society 25.

Sullivan, Timothy L.

n.d. Archaeological Investigations at Lake Bob Sandlin, Texas. Research Report 99. Archaeology Research Program, Southern Methodist University, Dallas.

Sussman, Lynne

1977 Changes in Pearlware Dinnerware, 1780-1830. Historical Archaeology 11:105-111.

Swanton, John R.

1939 Final Report of the United States De Soto Expedition Commission. 76th Congress, 1st Session, House Document No. 71. Washington, D.C.

1942 Source Material on the History and Ethnology of the Caddo Indians. Bureau of American Ethnology Bulletin 132. Washington, D.C.

Texas Parks and Wildlife Department

1983 Master Plan for Lake Bob Sandlin State Park, Titus County, Texas. Draft copy. Texas Parks and Wildlife Department, Austin.

Texas State Archives

1840 Request for pay to privates, David Patten, D. L. Ross, Ezeriah (?) Brackein, James Bailey, by Captain W. B. Stout.

Texas Water Development Board

1977 Continuing Water Resources Planning and Develpment for Texas, Cypress Creek Basin, vol. 1, part IV. Texas Water Development Board, Austin.

Thornthwaite, C. W.

1948 An Approach Toward a Rational Classification of Climate. Geographical Review $38: 55-94$.

Thurmond, J. Peter

1981 Archeology of the Cypress Creek Drainage Basin, Northeastern Texas and Northwestern Louisiana. M.A. thesis, The University of Texas at Austin.

Titus County, Texas

Deed Records

Turner, Robert L.

1978 The Tuck Carpenter Site and its Relation to Other Sites within the Titus Focus. Bulletin of the Texas Archeological Society 49:1-110. 
Winfrey, Dorman H.

1963 Diary of Major John Pollard Gaines. Texana 1(1):20-41.

Woodall, J. Ned

1967 The Harold Williams Site: A Preliminary Statement. Texas Archeology 11(4):7-10.

1969 Cultural Ecology of the Caddo. Ph.D. dissertation, Southern Methodist University, Dallas.

1972 Prehistoric Social Boundaries: An Archeological Model and Test. Bulletin of the Texas Archeological Society 43:101-120.

Wyckoff, Don G., and Timothy G. Baugh

1980 Early Historic Hasinai Elites: A Model for the Material Culture of Governing Elites. Midcontinental Journal of Archaeology 5(2):225-288.

Young, Wayne C.

1981 Test Excavations at the Tankersley Creek Site, a Multicomponent Campsite in Titus County, Texas. Publications in Archeology Report 22. State Department of Highways and Public Transportation, Highway Design Division, Austin. 